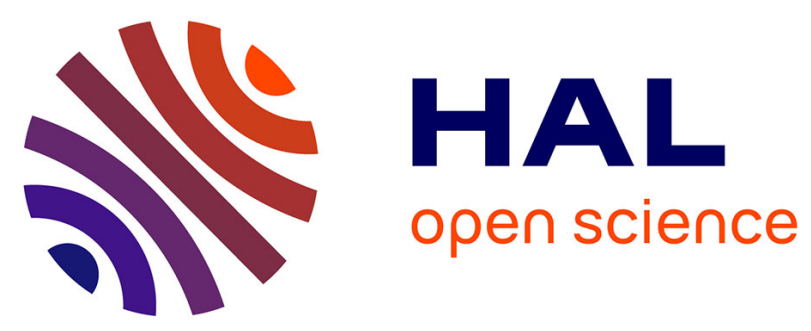

\title{
Spatial variability of phenology in two irrigated grapevine cultivar growing under semi-arid conditions
}

N. Verdugo Vásquez, C. Acevedo Opazo, H. Valdés Gómez, M. Araya Alman, B. Ingram, I. García de Cortázar-Atauri, B. Tisseyre

\section{- To cite this version:}

N. Verdugo Vásquez, C. Acevedo Opazo, H. Valdés Gómez, M. Araya Alman, B. Ingram, et al.. Spatial variability of phenology in two irrigated grapevine cultivar growing under semi-arid conditions. Precision Agriculture, 2015, 17 (2), pp.218-245. 10.1007/s11119-015-9418-5 . hal-01402332

\section{HAL Id: hal-01402332 \\ https://hal.science/hal-01402332}

Submitted on 24 Nov 2016

HAL is a multi-disciplinary open access archive for the deposit and dissemination of scientific research documents, whether they are published or not. The documents may come from teaching and research institutions in France or abroad, or from public or private research centers.
L'archive ouverte pluridisciplinaire HAL, est destinée au dépôt et à la diffusion de documents scientifiques de niveau recherche, publiés ou non, émanant des établissements d'enseignement et de recherche français ou étrangers, des laboratoires publics ou privés. 


\section{ABSTRACT} variability.

\section{SPATIAL VARIABILITY OF PHENOLOGY IN TWO IRRIGATED GRAPEVINE} CULTIVAR GROWING UNDER SEMI-ARID CONDITIONS Ingram $^{b}$, I. García de Cortázarc ${ }^{c}$ B. Tisseyre ${ }^{d}$



${ }^{\mathrm{b}}$ Universidad de Talca, Facultad de Ingeniería, 2 Norte, 685 Talca, Chile.

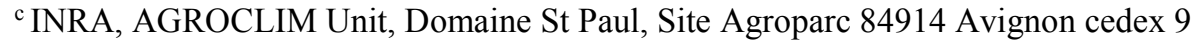

${ }^{\mathrm{d} M o n t p e l l i e r ~ S u p A g r o / I r s t e a, ~ U M R ~ I T A P, ~ B a ̂ t . ~ 21, ~} 2$ Pl. Pierre Viala, Montpellier 34060, France

${ }^{*}$ Corresponding author: e-mail: cacevedo@utalca.cl

Knowledge and monitoring of the grapevine phenology during the season are important requirements for characterization of productive regions, climate change studies and planning of various production activities at the vine field scale. This work aims at studying the spatial variability of grapevine phenology at the within field scale. It was conducted on two fields, one of cv Cabernet Sauvignon of 1.56 ha and the other of cv Chardonnay of 1.66 ha, both located in Maule Valley, Chile. Within each vine field, a regular sampling grid was designed, to carry out weekly measurements of phenology and maturation. The main results show that there is a significant spatial variability in the phenological development and maturation at the within field scale for both fields. This variability is spatially organised and temporaly stable from the beginning of the season (post-budburst) to harvest and over the years. A cluster analysis allowed us to define two clearly contrasted zones in terms of phenology and maturation in both fields, explained by the microclimate. The magnitude of difference between zones varied from 4 to 9 days depending on phenological stages and from 5 to 43 days for maturation. These differences are similar and comparable to that observed at larger scales or under scenarios of climate change. These results highlight the necessity to better take into account this variability to improve sampling and to base decisions of production activities (spraying, harvest, pruning, etc.) application on more relevant information. Further investigations should determine the environmental factors that determine the observed spatial

Keywords: Vitis vinifera, berry maturity, within field variability, temporal variability, management zones, climate change. 


$\begin{array}{lll}1 & \text { Abbreviations } & \\ 2 & & \\ & \text { CV } & \text { Coefficient of variation } \\ \text { DESP } & \text { Degree of spatial dependence } \\ \text { ET } 0 & \text { Reference evapotranspiration } \\ \text { Fl } & \text { Flowering } \\ \text { GDD } & \text { Growing degree-days } \\ \text { TSS } & \text { Total soluble solids } \\ \text { Ha } & \text { TSS measured at Days of the harvest } \\ \text { Ma } & \text { Maturation } \\ \text { MCD } & \text { Mean correlation distance } \\ \text { Max } & \text { Maximun } \\ \text { MI } & \text { Maturity index } \\ \text { Min } & \text { Minumun } \\ \text { Post-Bu } & \text { Post-budburst } \\ \text { Pre-Ha 1 } & \text { TSS measured at 25 days before harvest } \\ \text { Pre-Ha 2 } & \text { TSS measured at 12 days before harvest } \\ \text { PS } & \text { Units of Phenological Scale } \\ \text { Ps } & \text { Current phenological stage } \\ \text { Range } & \text { Range of variation } \\ \text { SD } & \text { Standard deviation } \\ \text { TSSV } & \text { Temporal Stability of the Spatial Variability } \\ \text { Ve } & \text { Veraison } \\ \text { W } & \text { Kendall coefficient of concordance }\end{array}$

\section{INTRODUCTION}

5 Grapevine phenology is the study of the stages of growth as budburst, flowering and veraison,

6 which are repeated every season and depend mainly on climatic and hormonal factors

7 (Mullins et al. 1992; Jones and Davis 2000). Knowledge and monitoring of the different

8 phenological stages of the grapevine during the season are important requirements for

9 planning of various production activities at the vine field scale (Mullins et al. 1992). For

10 example, for the management of powdery mildew in the vine there are control methodologies

11 based on the monitoring of the pathogen and plant phenology so as to make phytosanitary

12 applications at the most susceptible phenological stages (flowering and fruit set), thereby

13 reducing the number of phytosanitary treatments (Campbell et al. 2007; Bramley et al. 2011).

14 Likewise, for irrigation management it has been observed that the application of regulated

15 deficit irrigation on specific phenological periods of post-setting and post-veraison optimizes

16 the vegetative growth, the yield and the final quality of the berries (Ojeda et al. 2002;

17 Acevedo-Opazo et al. 2010). Moreover, knowing the phenological development of the vine 
Author-produced version of the article published in Precision agriculture, 2015, №17(2), p. 218-245. The original publication is available at http://link.springer.com

1 together with its fruit ripening makes it possible to optimize the harvesting process, often

2 supporting a differentiated management of vine fields (Trought and Bramley 2011).

3 The importance of monitoring the phenology of the vine as a decision support information

4 has motivated numerous investigations at different spatial scales, for example, at meso scale

5 (vineyards, more than 200 ha surface) models that predict phenological events have been

6 developed and can be used to plane farming operations at this scale (Ortega-Farías et al.

7 2002; García de Cortázar-Atauri et al. 2009; Caffarra and Eccel 2010; Nendel 2010; Parker

8 et al. 2011; Sadras and Petrie 2012). Moreover, phenological process based models have also

9 been used to assess the impact of climate change on the phenological development of

10 grapevines at macro scales (regions) (Marta et al. 2010; Moriondo et al. 2010; Caffarra and

11 Eccel 2010, 2011). There have also been studies on the spatial variability of the phenology

12 of grapevines at the macro scale, in order to determine optimum pedo-climatic zones for the

13 production of quality grapes (Tesic et al. 2001) and to establish spatial patterns of evolution

14 of berry maturity in different areas of Australia (Petrie and Sadras 2008).

16 With regard to the spatial variability of climate at the meso scale, in recent years the 17 TERADCLIM (Quénol and Bonnardot 2014) and ADVICLIM (Quénol et al. 2014) projects 18 modeled spatial variability of climate (temperature) in the main vine production areas of the 19 world. Assuming the availability of relevant calibrated model linking climate variables to 20 vine phenology, these projects may constitute relevant piece of information to model the 21 spatial variability of vine phenology.

22 Generally speaking, the findings reported in these researches have large spatial scale 23 applicabilities (macro and meso scales), which is at odds with the needs of growers for whom 24 the basic unit of management is the vine field (surface less than 5 ha, micro scale) which is 25 characterized by a same variety, training system and management practices.

26 In recent years, several authors have observed that in agriculture and especially in viticulture, 27 there is significant spatial variability at the micro scale (within field level) in the production 28 variables such as plant water status (Acevedo-Opazo et al. 2010; Acevedo-Opazo et al. 2013), 29 vegetative expression (King et al. 2014), yield (Bramley and Hamilton 2004; Tardaguila et 30 al. 2011) and the quality components of the berries (Bramley and Hamilton 2004; Baluja et 
1 al. 2013). This observed variability was mainly attributed to differences in soil (Tardaguila

2 et al. 2011).

3 In this light, one wonders whether the vine field is a unit of homogeneous management in

4 relation to the evolution of its phenological cycle during the season. If this is not the case,

5 then the methods traditionally used by wine producers to characterize the phenological stage

6 of their vine fields would not be appropriate to represent the spatial variability of the fields.

7 Indeed, in practice, wine industry does not carry out more than two phenological observations

8 per field. These two observations are assumed to be representative of the whole vine field

9 and sometimes to other neighbouring fields of the same variety. Thus, traditional methods

10 could result in inadequate decisions of interventions.

11 To our knowledge, studies on spatial variability on climate and phenology have focused at 12 macro or meso scale (surface > 200 ha) (Bonnefoy et al. 2012; Irimia et al. 2015; Quénol 13 2013; Quénol et al. 2014), without considering the micro scale (spatial scale $<5$ ha). The aim 14 of this study is therefore to investigate the spatial variability of grapevine phenology at the 15 within field scale, answering the following questions: i) is there a spatial variability in the 16 phenological development of the vine at the field scale? ii) is the spatial variability observed 17 stable over time? and iii) is it worth to define management zones in relation to the phenology 18 of the fields?

\section{MATERIALS AND METHODS}

\section{Experimental Fields}

22 The study was conducted in two fields, one of cv. Cabernet Sauvignon of 1.56 ha (field 1) 23 and the other of cv. Chardonnay of 1.66 ha (field 2), both located in the Panguilemo 24 Experimental Station of the University of Talca (Maule Valley), Chile (Fig. 1). The 25 characteristics of both fields are summarized in Table 1. The region is characterized by 26 Mediterranean climatic conditions, while the soil belongs to the Talca and San Rafael series 27 (Ultic Haploxeralfs) (Soil Survey Staff 1999). Both vineyards were managed according to 28 the conventional agricultural practices used in the commercial vineyards of central Chile in 29 terms of canopy management, fertilization, pest and disease control, pruning and irrigation, 30 over all the seasons of the study period. Within each vine field a regular sampling grid was 31 designed, one with 18 measurement sites $(25 \times 25 \mathrm{~m})$ for field 1 (Fig. 2 a) and one with 19 
1 measurement sites $(25 \times 25 \mathrm{~m})$ for field 2 (Fig. 2 b). Each site of the grid was represented by

2 four consecutive plants. The borders of the fields and sampling sites within each field were geo-referenced with a differential global positioning system receiver (DGPS) (Trimble,

4 Pathfinder ProXRS, Sunnyvale, California, USA) and stored as Eastern and Northern

5 coordinates (Datum WGS84, UTM projection, Zone 19S) to perform the mapping and spatial 6 analysis.

7 An automatic weather station (Adcon Telemetric, A730, Klosterneuburg, Austria) installed 8 under reference conditions, at $300 \mathrm{~m}$ from the vineyards, provided data such as air 9 temperature, relative humidity, solar radiation, precipitation, wind speed and direction of the 10 wind at 15-minute intervals. The sensors were installed at $2.5 \mathrm{~m}$ above the soil surface, except 11 for the temperature and relative humidity sensors which were located $1.5 \mathrm{~m}$ above the soil 12 surface. This information was used to estimate reference evapotranspiration $\left(\mathrm{ET}_{0}\right)$, using the 13 Penman-Monteith equation (Allen et al. 2006) and the sum of growing degree-days (GDD), 14 from $1^{\text {st }}$ May to harvest and for each phenological period considered (i.e. flowering or 15 veraison). Sum of GDD was calculated as the sum of the daily difference between the average 16 air temperature minus $10^{\circ} \mathrm{C}$ (Winkler 1974).

17 Additionally, considering that the main variable that affects phenological development of the 18 grapevine is the temperature (Chuine et al. 2013; Quénol et al. 2014), 8 temperature sensors 19 (Dickson, LogTK500, USA) were installed in the field 1 (cv Cabernet Sauvignon) with the 20 aim to characterize the spatial variability of temperature at the within field scale.

21 The sensors were located according to a preliminary analysis of the 2009-10 season. Two

22 zones of phenology were identified. Assuming temporal stability of these zones, 8 sensors (4 23 sensors for each zone) were installed (Fig. 3) at $1.5 \mathrm{~m}$ above the soil surface and on vine 24 rows. Temperature was recorded every 30 minutes in the period of September (before 25 budburst) until October (pre-flowering) during the 2011-2012 season, corresponding to a 26 total of 37 days of measurements.

\section{Measurements}

29 a) Grapevine Phenology

30 The phenological observations were made from budburst to veraison, every 7 days in 30 31 shoots chosen systematically among the 4 vines of a site of the grid. The same shoots were 
1 always measured date after date over a season. On each site of the grid, mean value of

2 phenology measured over the 30 shoots was calculated. Phenology was estimated using the 3 Eichhorn and Lorenz phenological scale as modified by Coombe (Coombe 1995) (Table 2).

4 It considers measurements of leaf number, length of shoots $(\mathrm{cm})$ and berry diameter $(\mathrm{mm})$.

5 The phenological scale assigns a number to each phenological measurement (expressed in 6 units of Phenological Scale, PS, Table 2), allowing us to represents phenology as a numeric 7 variable. For data analysis it was used only the three major phenological stages (post8 budburst, flowering and veraison). Veraison for cv Cabernet Sauvignon was considered by 9 berries colour change, while for cv Chardonnay it was considered by berry softness and 10 colour change simultaneously.

\section{1 b) Maturation (expressed as total soluble solids, TSS)}

12 From veraison to harvest, measurements of total soluble solids (TSS) were performed as 13 indicator of grapevine maturity. TSS was chosen as the most typical indicator used to define 14 harvest time. This measurement was done by a thermo-compensating refractometer (BRIX30 15 model, Leica, USA), by randomly selecting eight clusters from each site of the grid. For each 16 cluster two berries were sampled at the top, the middle and the bottom of the cluster. 17 Therefore, TSS value of each site of the grid and each date corresponded to a sample of 48 18 berries. Three sampling dates were considered, called Pre-Ha 1 (25 days before harvest), Pre19 Ha 2 (12 days before harvest) and Ha (Days of the harvest). For both fields, harvest (Ha) 20 was defined at $22^{\circ}$ Brix. This last value corresponding to the optimal maturity at harvest in 21 our conditions.

\section{Analysis method}

24 For main phenological stages and maturity dates, basic statistics such as standard deviation, 25 maximum/minimum values and coefficient of variation $(\mathrm{CV})$ were calculated. These 26 statistics were expressed in units of Phenological Scale (PS) and TSS ( ${ }^{\circ}$ Brix) respectively for 27 phenology and maturation.

28 A variographic analysis was performed to study the spatial structure of the phenological data 29 and the maturity at each date for both experimental fields. Omnidirectional semivariograms 30 were calculated according to the methodology proposed by Webster and Oliver (2001). The 
1 three basic parameters of the semivariogram were obtained: nugget $\left(\mathrm{C}_{0}\right)$, sill $\left(\mathrm{C}_{0}+\mathrm{C}_{1}\right)$ and

2 range (a), which define the degree and scale of spatial variation among the observations. The computation of a semi variogram is usually not recommended with a number of points as low

4 (Webster and Oliver 1992). However, for this experiment, the quality of data collected

5 (manual measurements averaged over a large number of individuals) and the significant 6 spatial organisation of the fields allowed us to consider such an analysis. From 7 semivariogram parameters the degree of spatial dependence (DESP) also called the 8 Cambardella index, was derived by using the ratio between the nugget and the total 9 semivariance of the semivariogram (sill), expressed as a percentage (Cambardella et al. 10 1994), Eq. 1.

$11 \operatorname{DESP}(\%)=\left[\frac{\mathrm{C}_{0}}{\mathrm{C}_{0}+\mathrm{C}_{1}}\right] * 100$

12 The Cambardella index allowed us to compare the relative size of the nugget effect for each 13 date of the experiment. Thus, the values of DESP $\leq 25 \%$ indicate a strong spatial 14 dependence; $25 \% \leq D E S P \leq 75 \%$ indicate a moderate spatial dependence, and the values 15 of DESP $>75 \%$ correspond to a weak spatial dependence (Wu et al. 2008). In addition to 16 DESP, the mean correlation distance (MCD) (Han et al. 1996) was estimated (Eq. 2).

$17 \operatorname{MCD}(m)=\frac{3}{8} *\left[\frac{\mathrm{C}_{1}}{\mathrm{C}_{0}+\mathrm{C}_{1}}\right] * \mathrm{a}$

18 The MCD provided an estimate of the distance at which the data have a high spatial 19 dependence (Han et al. 1996).

20 Mapping spatial distribution

21 Maps with both phenological and maturation variables were done in order to visualize the 22 phenology and maturation of the fields. To this end, the method of interpolation Block23 Kriging as proposed by Baluja et al. (2013) was used. The scale of the maps was defined 24 using an equidistant range, with two intervals.

25 Analysis of the Temporal Stability of the Spatial Variability (TSSV) of the grapevine 26 phenology and maturation

27 To quantify the TSSV of both phenology and maturation, the Kendall coefficient of 28 concordance (W) was calculated according to the methodology described by Tisseyre et al. 29 (2008). W ranges from 0 , in the case of no temporal stability (total desagreement in site order 
Author-produced version of the article published in Precision agriculture, 2015, №17(2), p. 218-245.

The original publication is available at http://link.springer.com

Doi: $10.1007 / \mathrm{s} 11119-015-9418-5$

1 between dates), to 1 in the case of temporal stability (Saporta 1990). This analysis was carried

2 out in two ways:

3 - to quantify the TSSV of phenology and maturity over the seasons, it was performed

4 separately on the main phenological stages (post-budburst, flowering and veraison) and on

5 the maturation (Pre-Ha 1, Pre-Ha 2 and Ha),

6 - to quantify the intra-season TSSV, it was performed on the main phenological stages and

7 maturation dates measured within each season.

8 Zoning of the vine fields based on grapevine phenology and maturation

9 For each field, the zoning of both phenology and maturation was conducted with a cluster

10 analysis using the centroid squared euclidean distance (Flores 2005). For phenology zones

11 most relevant phenological stages of the vineyard management (post-budburst, flowering and

12 veraison) were considered while three main dates (Pre-Ha 1, Pre-Ha 2 and Ha) were

13 considered for maturation. For both fields and each dates, two clustering operation were

14 therefore performed, one related to phenology and the other one to maturation. The clustering

15 was conducted to provide two classes for each field under consideration. Considering the

16 high spatial organisation of our data, this clustering method was expected to highlight within

17 field zones. In the rest of the document, zones will refer to the classes resulting from the

18 clustering.

Phenological and maturation characterization expressed in days

a) Grapevine Phenology

22 In order to provide a practical interpretation of the spatial variability in the phenology 23 observed between budbreak and veraison, the observed phenological stage was turned into 24 chronological days for both fields. This transformation was performed through the 25 implementation of a predictive model of phenology following to the methodology proposed 26 by Ortega-Farías et al. (2002). This model uses the monomolecular Mitscherlich equation 27 (Thornley and Johnson 1990), (Eq. 3). It estimates the phenological stage (expressed in units 28 of Phenological Scale, PS) in terms of thermal accumulation from the time of the budburst. 29 Based on observed values and meteorological data, the model was calibrated for each 30 cultivar. Resulting model allowed us to estimate the growing degree-days required to fulfill 31 a certain phenological stage. Fig. 4 represents the simulation of the proposed model for cv 
1 Cabernet Sauvignon and cv Chardonnay. On Fig. 4, vertical lines cutting x-axis correspond

2 to the sum of GDD necessary to reach flowering ( $\mathrm{PS}=23)$. This approach is similar to that

3 used in studies conducted by Jorquera-Fontena and Orrego-Verdugo (2010) who studied the

4 effect of climate change on the phenological development of the vine.

$5 \quad P s=P s_{f}-\left(P s_{f}-P s_{i}\right) e^{-k(s G D D)}$

7 Where: $P s=$ current phenological stage (PS), $P_{s_{f}}=$ last phenological stage corresponding to $8 \mathrm{PS}=38, P_{s_{i}}=$ first phenological stage corresponding to $\mathrm{PS}=4, k=$ rate of phenological 9 development and sGDD $=$ sum of Growing degree-days $\left({ }^{\circ} \mathrm{C}\right)$ from the date corresponding to $10 P s_{i}$ to the date of $P s$.

12 Knowing observed GDD of each day from climatic data, Eq. (3) allowed us to transform PS 13 values in a number of days necessary to reach the phenological stage (Ps) under 14 consideration. At the field level, this approach was used to determine the number of days 15 required to achieve a given phenological stage (Dat $t_{F i}$ ) considering the mean of PS 16 observations on all sampling sites. It was also used to determine the number of days required 17 to achieve a given phenological stage for a within field zone (Datzi) by considering the mean 18 of PS observations belonging to the considered zone. For a given phenological stage, this 19 methodology was used to determine the difference, expressed in days between the average 20 of the whole field and the specific zones of the same field (Eq. 4).

22 Difference in days $=D a t_{F i}-$ Dat $_{Z i}$

24 Where: $D a t_{F i}=$ estimated date of the phenological stage $i$ for the whole field, $D_{a t}=$ 25 estimated date of the same phenological stage $i$ for the within field zone $Z$. Phenological 26 stages $i$, corresponds to $i=$ post-budburst, flowering and veraison.

b) Maturation

29 For maturation the three dates (Pre-Ha 1, Pre-Ha 2 and Ha) were transformed into days 30 through the implementation of a maturity index (MI). The MI quantifies the increase in TSS 31 ( ${ }^{\circ}$ Brix) for each degree-day accumulation (Eq. 5): 
$1 \quad M I=\frac{S S_{H}-S S_{M}}{\sum_{j=1}^{n} G D D}$

2 Where: $\mathrm{MI}=$ maturity index $\left({ }^{\circ} \mathrm{Brix} \mathrm{d}{ }^{\circ} \mathrm{C}^{-1}\right) ; S S_{H}=$ total soluble solids measured at harvest

3 ( ${ }^{\circ}$ Brix); $S S_{M}=$ total soluble solids measured at post-veraison (15 days after veraison, TSS

$4>15^{\circ}$ Brix $)$; GDD = growing degree day $\left({ }^{\circ} \mathrm{C} \mathrm{d} \mathrm{d}^{-1}\right) ; j$ corresponds to the measurement day of

$5 \quad S S_{M}$ and $n$ to the day of $S S_{H}$.

6 This approach assumes that after a period of rapid increase in TSS (at veraison), TSS

7 increases linearly over time (Sadras and Petrie 2012). The MI was estimated for both fields,

8 obtaining a specific value for each cultivar. $S S_{M}$ and $S S_{H}$ were estimated by averaging values

9 measured over the whole field for each field. MI was used to estimate the number of days

10 explaining observed difference in maturity between the whole field and the within field

11 zones. (Eq. 6).

13 Difference in days $=\frac{S S_{F i-} S S_{Z i}}{\mathrm{MI} * G D D_{A}}$

14 Where: $S S_{F i}=$ average total soluble solids of all sampling sites of the fields at date $i$ ( ${ }^{\circ}$ Brix);

$15 S S_{Z i}=$ average total soluble solids of the sites belonging to zone $z$ at the same date $i$ ( ${ }^{\circ}$ Brix),

$16 i$ is the date of measurement corresponding to Pre-Ha 1, Pre-Ha 2 and Ha. MI = Maturity

17 Index ( ${ }^{\circ}$ Brix $\left.\mathrm{d}^{\circ} \mathrm{C}^{-1}\right) ; G D D_{A}=$ Daily mean of GDD from post-veraison (15 days after

18 veraison) to harvest $\left({ }^{\circ} \mathrm{C} \mathrm{d}^{-2}\right)$.

20 Software and Tools

21 For the classical statistical analysis, the Statgraphics Plus 5.1 (StatPoint Inc., Virginia, USA)

22 software was used, while for the geostatistical analysis, the $G S+$ version 9.0 (Gamma Design

23 Software, LLC, 2008) software was used. For the design of the maps the 3DField (version

24 2.9.0.0., Copyrigtht 1998 - 2007, Vladimir Galouchko, Russia) software was used. Finally,

25 the Matlab Software (The Mathwork Inc., Natick, MA, USA) was used for the calculation

26 related to phenology model.

27

28

RESULTS AND DISCUSSION

29 Climate characterization 
Author-produced version of the article published in Precision agriculture, 2015, №17(2), p. 218-245. The original publication is available at http://link.springer.com Doi: $10.1007 / \mathrm{s} 11119-015-9418-5$

1 The climatic characterization for all the study seasons is presented in Table 3. The mean air

2 temperature during the period between $1^{\text {st }}$ May and the harvest ranged between 15 and 15.7

$3{ }^{\circ} \mathrm{C}$. The third season (2011-12) presents the highest temperature, showing this season was

4 warmer (with mean temperature values above $20^{\circ} \mathrm{C}$ ) during the period from flowering to

5 harvest. These temperatures lead to higher sum of growing degree-day values, which

6 fluctuated between 1455 and $1640{ }^{\circ} \mathrm{C} \mathrm{d}^{-1}$ for field 1 (cv Cabernet Sauvignon) and between

$7 \quad 1385$ and $1523{ }^{\circ} \mathrm{C} \mathrm{d}^{-1}$ for field 2 (cv Chardonnay). These values are well above the 1150 and

$81300{ }^{\circ} \mathrm{C} \mathrm{d}^{-1}$ considered adequate to properly mature respectively, cv Chardonnay and $\mathrm{cv}$

9 Cabernet Sauvignon (Gladstones 1992). Regarding the precipitation, these were mainly

10 similar during the last three seasons and 23\% lower during the first season (2009-2010). As

11 a result of the low rainfall and evapotranspiration, a climate water deficit $\left(\mathrm{P}_{-}-\mathrm{ET}_{0}\right)$ was

12 observed, which fluctuated between 464 and $553 \mathrm{~mm}$ for the different seasons; the first

13 season showed the lowest water deficit. Finally, the climatic conditions of the seasons studied

14 can be considered similar, except the 2012-2013 season which presents higher sGDD value.

15 Non-spatialized analysis of the grapevine phenology and maturation

16 Main statistics of the phenology and the maturity are presented in Table 4 and Table 5

17 respectively. For field 1, the phenological stages of post-budburst, flowering and veraison

18 presented a range of variation between 1 and 6 units on PS for the 4 seasons. Meanwhile, for

19 field 2, these ranges varied between 2 and 5 units of PS (Table 4). For both fields the stage

20 of veraison presented the lowest dispersion during seasons (smallest range). For the

21 maturation period, ranges of variation varied from 3.6 to $6.0^{\circ}$ Brix for field 1 whereas for

22 field 2 they varied from 2.7 to $4.9^{\circ}$ Brix (Table 5). With regards to the variability between

23 seasons, the range values remained similar over the seasons, suggesting that there is a

24 temporal stability in the dispersion of the phenological stages and maturation.

25 The coefficients of variation (CV) for both fields show that the phenological stage with the

26 greatest variation during all the seasons was post-budburst, with values that ranged between

278.3 to $12.8 \%$ and 6.4 to $15.6 \%$ for field 1 and field 2 respectively. The veraison presented the

28 lowest variability. In both fields and over all seasons of the experiment, CV value decreases

29 from post-budbreak to veraison. This result may be due to the proposed scale (Table 2) which

30 is less sensitive to the changes observed at veraison. During maturation, CV values did not

31 show great variations within each season. 
Author-produced version of the article published in Precision agriculture, 2015, №17(2), p. 218-245.

The original publication is available at http://link.springer.com

Doi: $10.1007 / \mathrm{s} 11119-015-9418-5$

1 Regarding the literature dealing with spatial variability at the within field scale, to our

2 knowledge, no reference on $\mathrm{CV}$ values for the phenological stage is available. Concerning

3 the maturation, especially for harvest, Baluja et al. (2013) obtained CV values for total

4 soluble solids measured during the harvest ranging between 5.3 and $7.5 \%$ for $\mathrm{cv}$ Tempranillo

5 in Spain. These values are similar to that observed in the present study. Similar range of

6 variation were also observed by Tisseyre et al. (2008) and Bramley (2005) for TSS at harvest.

7 This first analysis highlight variability in the phenological development and maturation at

8 the within field scale. Next sections aim at studying whether this variability is organised

9 spatialy and if the observed variability is significant enough to justify site specific

10 managements.

\section{Spatial variability of the grapevine phenology and maturation}

12 The semivariogram model which was generally better adjusted to the different phenological 13 stages and maturation dates was the Gaussian model, with $\mathrm{r}^{2}$ values ranging between 0.67 14 and 0.99 (Table 6 and 7). A significant variation is also observed in the range of the 15 semivariogram which fluctuated between 22.8 and $150 \mathrm{~m}$ (Table 6 and 7). The range is in 16 almost all cases higher than the sampling distance $(25 \mathrm{~m})$. This indicates the sampling 17 distance is large enough to highlight the spatial variation. Range of the semi variogram 18 exceeds in almost all cases length of the fields, showing the presence of a non-stationary 19 phenomenon.

20 For all seasons, all phenological stages and almost all maturation dates, a strong spatial 21 dependence (DESP) was observed (Table 6 and 7). Indeed values of DESP are lower or 22 equal to $25 \%$. These results agree with those obtained by Baluja et al. (2013) at least for TSS 23 measured at harvest.

24 The identification of a non-random spatial structure, for all the seasons throughout phenology 25 and maturation could be explained by the environmental factors of the fields, such as the soil 26 conditions and topography and their resulting effect on the microclimate of the canopy (Tesic 27 et al. 2001). Thus, more research should be conducted to determine more precisely which 28 factor or set of factors impact the within field microclimate and determine the spatial 29 structure observed in phenology and maturation.

30 Fig. 5 and Fig. 6 show the spatial distribution of the main phenological stages and maturation 31 respectively for field 1. Fig. 7 and Fig. 8 show the spatial distribution of the main 
1 phenological stages and maturation for field 2. For both fields and almost all the maps, two

2 well-contrasted zones resulting from the clustering method can be observed. For field 1,

3 more advanced phenological stages and maturation are observed in the North-Western part

4 of the field. This zone is rather flat and is characterised by a deeper soil and less inclination.

5 Meanwhile, for field 2 more advanced phenological stages and maturation occur in the

6 southern part of the field. This latter zone is located in a slightly lower position, characterized

7 by a higher total soil water availability (data not shown).

9 Relationship with canopy temperature

10 Regarding results of temperature sensors (Fig. 9) a relationship between phenology and

11 canopy temperature is clearly highlighted. There are important differences in temperature

12 between zones (defined in Fig. 3) throughout the 37 days of measurements (Fig. 9 a) for field

13 1. Sensor located in zone 1 (Fig. 3) showed higher temperature and GDD (Fig. 9 b), which

14 may explain more advanced phenology and maturation stages (Fig. 5 and Fig. 6). The

15 difference in temperature between zones was $0.4{ }^{\circ} \mathrm{C}$ per day and 15 GDD (between DOY

16257 and 293).

17 Variability observed in both phenology and maturation (Fig. 5 and 6) may correspond to

18 zones where microclimatic conditions are different. In our conditions, at within field scale,

19 we can hypothesize that stable factors as differences in soil type, slope, topography and

20 vegetative expression, could explain these differences in microclimatic conditions

21 (temperature) and consequently differences in grapevine phenology and maturation. Then,

22 determination of environmental factors which drive grapevine phenology and climate

23 variability at the within field scale could constitute interesting investigations to map spatial

24 variability of grapevine phenology at this scale.

\section{Temporal variability of the grapevine phenology and maturation}

27 The spatial distribution of all maps (Fig. 5, 6, 7 and 8) presents fairly constant and well 28 defined spatial patterns. These latter remain stable within each season and between seasons.

29 This stability is observed for both fields. Baluja et al. (2013) reported a high temporal 30 stability of spatial patterns of the TSS measured at harvest over 3 seasons in a plot of 2.2 ha 31 of the cultivar Tempranillo in Navarra, Spain. In turn, results obtained by Bramley (2005) 
1 and Tisseyre et al. (2008) show that spatial patterns were not as stable over time for the same

2 variable. In this way, the temporal stability is probably a characteristic of the specific

3 conditions of each of the experimental sites, such as the weather and soil conditions and the

4 choice of harvest date (Tisseyre et al. 2008; Baluja et al. 2013). It is worth mentioning that,

5 in the present investigation, the environmental conditions over the seasons were quite similar

6 (Table 3) and that the harvest date was considering when mean of the field reached $22^{\circ} \mathrm{Brix}$

7 for each seasons, which would explain the stability of the observed patterns.

9 The Kendall coefficient of concordance W (Table 8 and 9) was used to quantify the TSSV 10 of phenological stages and maturation. Results of TSSV between seasons are shown in Table 11 8. Observed $\mathrm{W}$ values are high $(\mathrm{W}>0.5)$ and statistically significant for both fields either 12 for phenology or maturation. This result corroborates the temporal stability observed on 13 maps presented previously (Fig. 5, 6, 7 and 8).

14 Results of within season TSSV are shown in Table 9. For both fields, observed W values are 15 high and statistically significant either for phenology $(\mathrm{W}>0.54)$ or maturation $(\mathrm{W}>0.78)$.

16 This high TSSV observed within each season suggests that information generated at the 17 beginning of the season (post-budburst) can be used at a later date to characterize the spatial 18 variability of both phenology and maturation.

\section{Zoning of the vine fields according to their phenology and maturation}

21 The cluster analysis allowed us to define two clearly contrasted zones in terms of phenology 22 (Fig. $10 \mathrm{a}$ and b) and maturation (Fig. $10 \mathrm{c}$ and d). As expected, zones obtained from the 23 cluster analysis were very similar to zones observed on Fig. 5 to 8. Regarding the phenology, 24 zone 1 (cluster 1) represents $78 \%$ and $42 \%$ of the area of the field 1 and 2, respectively (Fig. $2510 \mathrm{a}$ and $\mathrm{b}$ ). For the maturation, zone 1 (cluster 1 ) represents $89 \%$ and $58 \%$ of the area of the 26 field 1 and 2, respectively. Zone 1 presents the most advanced phenological stages (highest 27 values of PS) and most advanced maturation (highest values of TSS), for both fields. Zones 28 presented in Fig. 10 (a, b, c and d) integrates all the dates of the seasons. Therefore they 29 highlight possible management zones. High similarity is observed between zones defined 30 for phenological stage and maturity for both fields. The zone 1 of field 1 differ only in 1 site 31 of the grid between phenology and maturation, while for field 2, it differs in 3 sites. This 
1 suggests a strong relationship between the phenological development of the grapevine and

2 the maturation. Parker et al. (2014) observed that differences in maturation (expressed in 3 TSS) at harvest were the result of changes observed at the onset of maturation, during 4 veraison. Therefore, variability of phenology, for example at veraison, may constitute a

5 relevant decision support to define harvest zones of different quality early in the season.

6 In order to verify the opportunity to manage specifically zones identified on our experiments,

7 analysis of the delay in term of days has been performed. This analysis is presented in the

8 next section.

Grapevine phenology and maturation expressed in days

11 From an operational point of view, vinegrowers need to quantify the difference in days 12 among the different phenological stages and maturation of the zones so as to plane their work.

13 Thus, the numeric phenological stage was turned into chronological days through the 14 implementation of a predictive model of phenology (Ortega-Farías et al. 2002). The 15 calibration of this predictive model (Eq. 3) with our data led to a fit of $\mathrm{R}^{2}=0.99$ for both 16 cultivars. In the same way the maturity index (MI) used to turn into chronological days the 17 difference in maturation (TSS, ${ }^{\circ}$ Brix) yielded a value of 0.01 and $0.02{ }^{\circ} \mathrm{Brix} \mathrm{d}^{\circ} \mathrm{C}^{-1}$ for the cv 18 Cabernet Sauvignon and cv Chardonnay, respectively. Differences between MI values is 19 explained by the precocity of each cultivars.

20 Fig. 11 present results of the difference between within field zones relative to the mean field 21 considered as reference level equal to 0. Positive values refer to advance in phenological 22 stage and maturation, while negative values refer to delay in these parameters.

23 For field 1 differences between each zone of the fields ranges from 3 to 5 days depending on 24 the phenological stage considered and from 35 to 36 days depending on the maturity dates 25 considered (Fig. 11 a). Regarding zone 2, it presents the highest deviation from the mean of 26 the field. This is because zone 2 represents a small part of the field, therefore mean field is 27 logically, closer to the mean of the zone 1.

28 For field 2 (Fig. 11 b), observed differences in post-budburst (3 to 4 days) increase slightly 29 in subsequent phenological stages, showing the veraison as the phenological stages that 30 presents the highest difference (5 days) with respect to the mean field (value 0). For 31 maturation, differences between 3 and 5 days were observed. In general, differences observed 
1 for field 2 are much smaller than those observed for field 1. This suggest that factors that

2 explain observed differences in both fields may be different or present a lower magnitude of

3 variation in field 2. The magnitude of difference (in days) between zones varied from 4 to 7

4 days for the phenological stages of field 1, with flowering presenting the higher difference.

5 Regarding the maturity of field 1, the difference between zones varied from 42 to 43 days.

6 For field 2, difference varied from 6 to 9 days for phenology, with veraison presenting the

7 higher difference between zones. For maturity of field 2, this difference varied from 5 to 8

8 days. The variability of the phenological stages expressed in days (Fig. 11) was higher for

9 veraison in both fields. Indeed it can be related to the subjectivity of measuring this stage

10 (associated with colour change estimated visually), therefore the definition of zones within

11 field could reduce variability to estimate this phenological stage, improving the accuracy of

12 the estimation. With respect to maturation, variability in days was higher for field 1.

\section{General discussion}

15 This work showed that there is a significant spatial variability in the phenological 16 development and maturation within the studied vine fields. This variability was spatially 17 organised and temporally stable from the beginning of the season (post-budburst) to harvest 18 and over the years. This suggests that factors explaining this phenomenon would be related 19 to stable parameters of the environment affecting microclimate conditions. This effect may 20 be emphasized by the perennial specificity of grapevines. It was shown, for one field that the 21 phenology and maturation zones correspond to zones where the microclimate was different.

22 The observed differences in the microclimate of the field 1 can be explained by stable 23 environmental factors (soil characteristics, slope, soil texture, presence of groundwater and 24 compacted strata that limit the growth of the root, etc.), ie, the spatial variability of stable 25 environmental factors produced differences in the microclimate of each zone, which affected 26 the phenology and maturity of the grapevine. This explains the observed high stability of 27 zones between different seasons for field 1. There is no information on factors that determine 28 the spatial variability of both microclimate conditions and phenological development at the 29 within field scale in the litterature. 
1 These results generate new questions concerning the modelling of the spatial variability of

2 the grapevine phenology at the within field scale. Two approaches may be considered for

3 further experiments: a) microclimate monitoring from wireless temperature sensors network,

4 such as works carried out at the meso scale level (Quénol et al. 2014). However, it is

5 important to define the number of sensors to be installed, location of those in the field and

6 the maintenance cost of the system which may limit its practical application (Kunz and

7 Tatham 2012; Primicerio et al. 2013). b) Characterisation of environmental factors at a high

8 spatial resolution. This approach corresponds to using high spatial resolution data

9 (topography, soil characteristics, slope) with low operational costs, for example, obtained by

10 unmanned aerial vehicle (Matese et al. 2015). Assuming these factors explain the spatial

11 variability of microclimate and the resulting variability in phenology and maturity, an

12 empirical model combining observations and high resolution spatial data could be considered

13 to model the microscale spatial variability of the phenology. The methodology used for the

14 water status in grapevines (Acevedo-Opazo et al. 2010) could be a relevant approach in this

15 case.

17 The observed within field differences may have important implications for crop management.

18 The goal of the following section is to identify the opportunity to manage the observed within

19 field variability for each phenological stages as well as for maturity.

20 For post-budburst, observed magnitude of variation may have practical applications

21 concerning spring freeze event. Susceptibility of the buds to spring frost depends on the

22 phenological stage of buds (Friend et al. 2011). On a controled experimentation, Friend et al.

23 (2011) shown effect of frost was different when occuring on two treatments characterized by

24 a difference of 1 PS (corresponding to 4 days in our study). A significant increase in primary

25 shoots death for the most advanced treatment (at budburst) was observed while reduced

26 dammages were observed in delayed treatment. Differenciate effect of frost had a significant

27 impact on yield at harvest. In our study, observed difference of 4 to 8 days (Fig. 8 a and b)

28 corresponding to 2-3 PS (Fig. 3 and 5) for post-budburst could lead to significant differences

29 between zones in case a frost event occurs at this period. Practicaly, the delineation of

30 phenology zones is hardly manageable at this stage since spring frost events are hardly

31 predictible. However, when it occurs, differential effect of the frost may be of importance to 
Author-produced version of the article published in Precision agriculture, 2015, №17(2), p. 218-245.

The original publication is available at http://link.springer.com

Doi: $10.1007 / \mathrm{s} 11119-015-9418-5$

1 understand the resulting within field yield variability and to consider site specific

2 management operations later in the season.

4 Flowering is considered as a critical stage for disease development such as powdery mildew 5 and botrytis (Campbell et al. 2007). Therefore, this stage determines the application date of 6 specific pesticides to control these diseases (Bramley et al. 2011). Thus, a delay in fungicide 7 application, waiting for the slowest zone of the field to reach the flowering stage, could 8 impact negatively on the proper control of the most advanced zones. In our study, the average 9 differences between the zones were 7 days for field 1 and 6 days for field 2. To our 10 knowledge, there is no information in the literature dealing with the effect of application time 11 on diseases control. However our study provides new background information on the spatial 12 variability of flowering. This results opens opportunities to better understand the success or 13 failure of control strategies and the resulting within field variability of diseases. Information 14 on the spatial variability of the incidence and severity of diseases in vineyards is scarce. 15 Bramley et al. (2011) found that incidence and severity of the two main diseases (powdery 16 mildew and botrytis) was spatially variable at the within field scale. The same authors 17 observed that diseases development was associated to the topography (slope), they 18 hypothetised that topography explained differences in microclimate more or less favorable 19 to diseases development. Regarding our results, it can also be hypothesized that topography 20 and the resulting microclimate could affect the date of flowering. Considering homogeneous 21 pesticides application over the vineyards, protection associated with the applications may 22 vary according to spatial variability of flowering. Therefore, spatial variability of diseases 23 may be due to either differences in phenology (and resulting pesticides efficiency) or to 24 environmental factors that directly affect diseases development (Valdés-Gómez et al. 2011). 25 These considerations highlight the necessity to take into account the spatial variability of 26 phenology (and especialy flowering) to better understand factors that affects diseases 27 variability. Specific experiments based on phenology maps and differencial application of 28 pesticides should be considered to properly analyse the spatial variability of diseases 29 development at the within field scale. 
Author-produced version of the article published in Precision agriculture, 2015, №17(2), p. 218-245. The original publication is available at http://link.springer.com Doi: $10.1007 / \mathrm{s} 11119-015-9418-5$

1 Regarding the period going from fruit setting to veraison, it is of critical importance to

2 manage irrigation. Spatial variability of phenology may be a relevant decision support to consider site specific management zones of regulated deficit irrigation strategies in such a way to optimize the final quality of the grapes (Ojeda et al. 2002; Acevedo-Opazo et al. 2005; Girona et al. 2009; Acevedo-Opazo et al. 2010). For veraison, Parker et al. (2014) observed

7 confirms our results of the temporal stability of the zones of phenology and maturity.

8 Therefore, phenology maps may be useful to determine maturity zones at the within field 9 scale. These maturity zones are the basis of a decision support to manage grape quality at 10 harvest by considering, for exemple differential harvest over time and/or space (Bramley 11 2005). Note that in our experiment, differential harvest would be of great interest in the field 12 1. Indeed, for this field, zone 2 never reaches the expected maturity. This is probably due to 13 the specific soil conditions associated to inadequate irrigation management (Acevedo-Opazo 14 et al. 2013). In this case, zone 2 could be harvested separately.

Identifying the spatial variability of the phenology could be a useful decision support to suggest management strategies that seek to homogenize the vine field phenology. Authors have reported that a late winter pruning operations delayed by 4-5 days the date of budburst (Dunn and Martin 2000). Thus, site specific pruning operation could reduce differences in phenological development. More generaly, our study points out the interest in delineating phenology zones to optimise field sampling and to improve the efficiency of the various agricultural operations and decisions during the season.

This work focused on the variability of the phenology at the within field scale. For terroir delineation or climate change monitoring purposes, other studies focused on the phenology and its variability at meso scale (Barbeau et al. 1998; Webb et al. 2007). At the regional scale (denomination of Loire Valley, France), Barbeau et al. (1998) found differences in dates of budburst, flowering and veraison ranging from 6 to 8 days on cv Cabernet Franc. At the same scale Webb et al. (2007) in Australia and Valdés-Gómez et al. (2011) in Chile, reported the results of simulations on the effect of climate change on the phenological development of the grapevine. Under different climate change scenarios, these authors reported advances in 
1 budburst date ranging from 4 to 12 days for cv Cabernet Sauvignon. It is interesting to note

2 that phenology variability observed at larger scales or under scenarios of climate change is

3 similar and comparable to those obtained at the within field scale. This observation raises

4 new questions:

5 - on the sampling strategy aiming at characterising grapevine phenology of a field at this

6 scale. Indeed, regarding the observed within field variability, sampling quality is of

7 paramount importance to guarantee that differences in phenology is related to macro scale

8 factors and not to micro scale (within field) effects,

9 - on management practices adaptation to climate changes. Our work showed that observed

10 within field variability encompasses change in phenology estimated from climate change

11 scenarios. This may demonstrate the robustness of current vine fields to climate change since

12 within field zones may still be well adapted to the expected climate change.

\section{CONCLUSIONS}

15 To our knowledge, this is the first study highlighting within field spatial variability in the 16 phenological development of the grapevine and maturation simultenaously. In our 17 conditions, this variability proves to be spatially organised and temporal stable since 18 advanced and delayed zones remain stable throughout the growing season (from post19 budburst to harvest). It was possible to identify two well-contrasted zones of phenology and 20 maturity within each vine field. Observed magnitude of variation was similar to the one 21 observed at larger scales or under scenarios of climate change. These results should be

22 considered for the sampling strategy of phenology and maturation at within field scale and 23 for planning production activities. Differences in phenology may explain the spatial 24 variability observed in other variables such as yield and disease development. Further 25 investigations should determine the environmental factors which drive the observed spatial 26 variability in phenology and maturity, and if possible propose predictive models that consider 27 this variability.

\section{ACKNOWLEDGEMENTS}

30 The authors of this paper wish to thank FONDECYT Project 11110137, National CONICYT 31 Doctoral Fellowship 2013 N²1130504 and PIEI Program of Agricultural Adaptation to 
1 Climate Change funded by the University of Talca. Also, the authors would like to thank the

2 support of the Chilean project CD-UBB 1203.

\section{CONFLICT OF INTEREST}

5 The authors declare that they have no conflict of interest.

\section{REFERENCES}

Acevedo-Opazo, C., Ortega-Farias, S., \& Fuentes, S. (2010). Effects of grapevine (Vitis vinifera L.) water status on water consumption, vegetative growth and grape quality: An irrigation scheduling application to achieve regulated deficit irrigation. Agricultural Water Management, 97(7), 956-964.

Acevedo-Opazo, C., Tisseyre, B., Taylor, J. A., Ojeda, H., \& Guillaume, S. (2010). A model for the spatial prediction of water status in vines (Vitis vinifera L.) using high resolution ancillary information. Precision Agriculture, 11(4), 358-378.

Acevedo-Opazo, C., Ortega-Farías, S., Hidalgo, C., Moreno, Y., \& Córdova, F. (2005). Effects of different levels of water application in post-setting and post-veraison on wine quality cv . Cabernet Sauvignon. Agricultura Técnica, 65(4), 397-410.

Acevedo-Opazo, C., Valdés-Gómez, H., Taylor, J. A., Avalo, A., Verdugo-Vásquez, N., Araya, M. et. al. (2013). Assessment of an empirical spatial prediction model of vine water status for irrigation management in a grapevine field. Agricultural Water Management, 124, 58-68.

Allen, R. G., Pruitt, W. O., Wright, J. L., Howell, T. A., Ventura, F., Snyder, R., et al. (2006). A recommendation on standardized surface resistance for hourly calculation of reference ETo by the FAO56 Penman-Monteith method. Agricultural Water Management, 81(1-2), 1-22.

Baluja, J., Tardaguila, J., Ayestaran, B., \& Diago, M. P. (2013). Spatial variability of grape composition in a Tempranillo (Vitis vinifera L.) vineyard over a 3-year survey. Precision Agriculture, 14(1), 40-58.

Barbeau, G., Morlat, R., Asselin, C., Jacquet, A., \& Pinard, C. (1998). Behaviour of the Cabernet Franc grapevine variety in varios "Terroirs" of the Loire Valley. Influence of the precocity on the composition of the harvested grapes for a normal climatic year (Example of the year 1988). Journal International Des Sciences de La Vigne et Du Vin, 32(2), 69-81. 
Bonnefoy, C., Quénol, H., Bonnardot, V., Barbeau, G., Madelin, M., Planchon, O., et al. (2012). Temporal and spatial analyses of temperature in a French wine-producing area: The Loire Valley. International Journal of Climatology, 33(8), 1849-1862.

Bramley, R. G. V. (2005). Understanding variability in winegrape production systems 2 . Within vineyard variation in quality over several vintages. Australian Journal of Grape and Wine Research, 11(1), 33-42.

Bramley, R. G. V., Evans, K. J., Dunne, K. J., \& Gobbett, D. L. (2011). Spatial variation in response to "reduced input" spray programs for powdery mildew and botrytis identified through whole-of-block experimentation. Australian Journal of Grape and Wine Research, 17(3), 341-350.

Bramley, R. G. V., \& Hamilton, R. P. (2004). Understanding variability in winegrape production systems 1 . Within vineyard variation in yield over several vintages. Australian Journal of Grape and Wine Research, 10(1), 32-45.

Bramley, R. G. V., Ouzman, J., \& Boss, P. K. (2011). Variation in vine vigour, grape yield and vineyard soils and topography as indicators of variation in the chemical composition of grapes, wine and wine sensory attributes. Australian Journal of Grape and Wine Research, 17(2), 217-229.

Caffarra, A., \& Eccel, E. (2010). Increasing the robustness of phenological models for Vitis vinifera cv. Chardonnay. International Journal of Biometeorology, 54(3), 255-67.

Caffarra, A., \& Eccel, E. (2011). Projecting the impacts of climate change on the phenology of grapevine in a mountain area. Australian Journal of Grape and Wine Research, 17(1), $52-61$.

Cambardella, C. A., Moorman, T. B., Parkin, T. B., Karlen, D. L., Novak, J. M., Turco, R. F., et al. (1994). Field-Scale Variability of Soil Properties in Central Iowa Soils. Soil Science Society of America Journal, 58(5), 1501-1511.

Campbell, P., Bendek, C., \& Latorre, B. A. (2007). Riesgo de oídio (Erysiphe necator) de la vid en relación con el desarrollo de los racimos. Ciencia E Investigación Agraria, 34(1), $5-11$.

Chuine, I., Cortazar-atauri, G. De, Kramer, K., \& Hänninen, H. (2013). Plant Development Models. In M. D. Schwartz (Ed.), Phenology: An Integrative Environmental Science (pp. 275-293). Dordrecht: Springer Netherlands.

Coombe, B. G. (1995). Adoption of a system for identifying grapevine growth stages. Australian Journal of Grape and Wine Research, 1(2), 104-110. 
Dunn, G. M., \& Martin, S. R. (2000). Do temperature conditions at budburst affect flower number in Vitis vinifera L. cv. Cabernet Sauvignon? Australian Journal of Grape and Wine Research, 6(2), 116-124.

Flores, L. (2005). Variabilidad Espacial del Rendimiento de Uva y Calidad del Mosto en Cuarteles de Vid cv . Cabernet Sauvignon y Chardonnay en Respuesta a la Variabilidad de Algunas Propiedades del Suelo. Agricultura Técnica, 65(2), 210-220.

Friend, a. P., Trought, M. C. T., Stushnoff, C., \& Wells, G. H. (2011). Effect of delaying budburst on shoot development and yield of Vitis vinifera L. Chardonnay "Mendoza" after a spring freeze event. Australian Journal of Grape and Wine Research, 17(3), 378382.

García de Cortázar-Atauri, I., Brisson, N., \& Gaudillere, J. P. (2009). Performance of several models for predicting budburst date of grapevine (Vitis vinifera L.). International Journal of Biometeorology, 53(4), 317-26.

Girona, J., Marsal, J., Mata, M., Del Campo, J., \& Basile, B. (2009). Phenological sensitivity of berry growth and composition of Tempranillo grapevines ( Vitis vinifera L .) to water stress. Australian Journal of Grape and Wine Research, 15, 268-277.

Gladstones, J. (1992). Viticulture and environment. Adelaide: Winetitles.

Hall, A., Lamb, D. W., Holzapfel, B. P., \& Louis, J. P. (2010). Within-season temporal variation in correlations between vineyard canopy and winegrape composition and yield. Precision Agriculture, 12(1), 103-117.

Han, S., Evans, R. G., Schneider, S. M., \& Rawlins, S. L. (1996). Spatial variability of soil properties on two center-pivot irrigated fields. In Precision Agriculture (pp. 97-106). American Society of Agronomy, Crop Science Society of America, Soil Science Society of America.

Irimia, L. M., Patriche, C. V., Bucur, G. M., Quénol, H., \& Cotea, V. V. (2015). Spatial Distribution of Grapes Sugar Content and its Correlations with Climate Characteristics and Climate Suitability in the Huși (Romania) Wine Growing Region. Notulae Botanicae Horti Agrobotanici, 43(1), x-x. http://doi.org/10.15835/nbha4319673

Jones, G. V., \& Davis, R. E. (2000). Climate Influences on Grapevine Phenology , Grape Composition, and Wine Production and Quality for Bordeaux, France. American Journal of Enology and Viticulture, 51(3), 249-261.

Jorquera-Fontena, E., \& Orrego-Verdugo, R. (2010). Impact of Global Warming on the Phenology of a Variety of Grapevine Grown in Southern Chile. Agrociencia, 44(4), $427-435$. 
King, P. D., Smart, R. E., \& McClellan, D. J. (2014). Within-vineyard variability in vine vegetative growth, yield, and fruit and wine composition of Cabernet Sauvignon in Hawke 's Bay, New Zealand. Australian Journal of Grape and Wine Research, 20, 234246.

Kunz, T., \& Tatham, B. (2012). Localization in Wireless Sensor Networks and Anchor Placement. Journal of Sensor and Actuator Networks, 1(1), 36-58.

Marta, A., Grifoni, D., Mancini, M., Storchi, P., Zipoli, G., \& Orlandini, S. (2010). Analysis of the relationships between climate variability and grapevine phenology in the Nobile di Montepulciano wine production area. The Journal of Agricultural Science, 148(06), 657-666.

Martin, S. R., \& Dunn, G. M. (2000). Effect of pruning time and hydrogen cyanamide on budburst and subsequent phenology of Vitis vinifera L . variety Cabernet Sauvignon in central Victoria. Australian Journal of Grape and Wine Research, 6(1), 31-39.

Matese, A., Toscano, P., Di Gennaro, S. F., Genesio, L., Vaccari, F. P., Primicerio, J. et al. (2015). Intercomparison of UAV, Aircraft and Satellite Remote Sensing Platforms for Precision Viticulture. Remote Sensing, 7, 2971-2990.

Moriondo, M., Bindi, M., Fagarazzi, C., Ferrise, R., \& Trombi, G. (2010). Framework for high-resolution climate change impact assessment on grapevines at a regional scale. Regional Environmental Change, 11(3), 553-567.

Mullins, M. G., Bouquet, A., \& Williams, L. E. (1992). Biology of the Grapevine. New York, USA: Cambridge University Press.

Nendel, C. (2010). Grapevine bud break prediction for cool winter climates. International Journal of Biometeorology, 54(3), 231-41.

Ojeda, H., Andary, C., Kraeva, E., Carbonneau, A., \& Deloire, A. (2002). Influence of preand postveraison water deficit on synthesis and concentration of skin phenolic compounds during berry growth of Vitis vinifera cv. Shiraz. American Journal of Enology and Viticulture, 53(4), 261-267.

Ortega-Farías, S., Lozano, P., Moreno, Y., \& León, L. (2002). Development of models for predicting phenology and evolution of madurity in cv. Cabernet Sauvignon and Chardonnay grapevines. Agricultura Técnica, 62(1), 27-37.

Parker, A. K., De Cortázar-Atauri, I. G., Van Leeuwen, C., \& Chuine, I. (2011). General phenological model to characterise the timing of flowering and veraison of Vitis vinifera L. Australian Journal of Grape and Wine Research, 17(2), 206-216.

Parker, A. K., Hofmann, R. W., van Leeuwen, C., McLachlan, a. R. G., \& Trought, M. C. T. (2014). Leaf area to fruit mass ratio determines the time of veraison in Sauvignon Blanc 
Petrie, P. R., \& Sadras, V. O. (2008). Advancement of grapevine maturity in Australia between 1993 and 2006: putative causes, magnitude of trends and viticultural consequences. Australian Journal of Grape and Wine Research, 14(1), 33-45.

Primicerio, J., Matese, A., Gennaro, S. F. Di, Albanese, L., Guidoni, S., \& Gay, P. (2013). Development of an integrated, low-cost and open-source system for precision viticulture: from UAV to WSN. In EFITA-WCCA-CIGR Conference "Sustainable Agriculture through ICT Innovation" Turin, Italy (pp. 24-27).

Quénol, H. (2013). Analyse du climat aux échelles locales dans le contexte du changement climatique. Pollution Atmosphérique, 129-138.

Quénol, H., \& Bonnardot, V. (2014). A multi-scale climatic analysis of viticultural terroirs in the context of climate change : the "TERADCLIM" project. International Journal of Vine and Wine Sciences, 25-34.

Quénol, H., Grosset, M., Barbeau, G., Van Leeuwen, K., Hofmann, M., Foss, Miranda, C. (2014). Adapatation of viticulture to climate change: high resolution observations of adaptation scenarii for viticulture: The ADVICLIM European Project. Bulletin de l'OIV , 87, 395-406.

Sadras, V. O., \& Petrie, P. R. (2012). Predicting the time course of grape ripening. Australian Journal of Grape and Wine Research, 18(1), 48-56.

Saporta, G. (1990). Probabilité, Analyse des données et Statistique. Analyse des données et statistiques. Editions Technip (Vol. Ed. Techni).

Soil Survey Staff. (1999). A Basic System of Soil Classification for Making and Interpreting Soil Surveys second ed. Soil Use and Management (Vol. 17). Blackwell Publishing Ltd.

Tardaguila, J., Baluja, J., Arpon, L., Balda, P., \& Oliveira, M. (2011). Variations of soil properties affect the vegetative growth and yield components of "Tempranillo" grapevines. Precision Agriculture, 12, 762-773.

Tesic, D., Woolley, D. J., Hewett, E. W., \& Martin, D. J. (2001). Environmental effects on cv Cabernet Sauvignon ( Vitis vinifera L .) grown in Hawke's Bay, New Zealand . 1 . Phenology and characterisation of viticultural environments. Australian Journal of Grape and Wine Research, 8(1), 15-26.

Thornley, J. H. M., \& Johnson, I. R. (1990). Plant and crop modelling. New York, USA: Oxford University Press. 
Tisseyre, B., Mazzoni, C., \& Fonta, H. (2008). Whithin-field temporal stability of some parameters in viticulture: Potential Toward a Site Specific Management. Journal International Des Sciences de La Vigne et Du Vin, 42(1), 27-39.

Tisseyre, B., Ojeda, H., Carillo, N., Deis, L., \& Heywang, M. (2005). Precision Viticulture and Water Status: Mapping the Predawn Water Potential to Define within Vineyard Zones . In Information and Technology for Sustainable Fruit and Vegetable Production FRUTIC (pp. 337-346).

Trought, M. C. T., \& Bramley, R. G. V. (2011). Vineyard variability in Marlborough, New Zealand: characterising spatial and temporal changes in fruit composition and juice quality in the vineyard. Australian Journal of Grape and Wine Research, 17(1), 79-89.

Valdés-Gómez, H., Gary, C., Cartolaro, P., Lolas-Caneo, M., \& Calonnec, A. (2011). Powdery mildew development is positively influenced by grapevine vegetative growth induced by different soil management strategies. Crop Protection, 30(9), 1168-1177.

Valdés-Gómez, H., Brisson, N., Acevedo-Opazo, C., Gary, C. and Ortega-Farías, S. (2011). Modelling the effects of Niño and Niña events on water balance of grapevine (cv. Cabernet Sauvignon) in Central valley of Chile. Sixth International Symposium on Irrigation of Horticultural Crops. Acta Horticulturae 889:159-166.

Webb, L. B., Whetton, P. H., \& Barlow, E. W. R. (2007). Modelled impact of future climate change on the phenology of winegrapes in Australia. Australian Journal of Grape and Wine Research, 13, 165-175.

Webster, R., \& Oliver, M. (2001). Geostatistics for environmental scientists. Statistics in practice., Chichester, England.

Webster, R., \& Oliver, M. A. (1992). Sample adequately to estimate variograms of soil properties. Journal of Soil Science, 43(1), 177-192.

Winkler, A., Cook, J., Kliewer, W., \& Lider, L. (1974). General Viticulture (2nd Ed.). CA, USA: University of California.

Wu, C., Wu, J., Luo, Y., Zhang, L., \& DeGloria, S. (2008). Spatial Prediction of Soil Organic Matter Content Using Cokriging with Remotely Sensed Data. Soil Science Society of America Journal, 73(4), 1202-1208.

\section{LIST OF FIGURES}

Fig. 1 Location of Maule Valley in Chile (a) and map of the study area (b)

Fig. 2 Measurement grids used in the experiments. 18 grid sites for field 1, cv Cabernet Sauvignon (a) and 19 sites for field 2, cv Chardonnay (b). Where: $S_{i}$ represents the sampling site number i 
Fig. 3 Location of temperature sensors in the field 1 (cv Cabernet Sauvignon). Where: Z1 represents zone 1 and $\mathrm{Z} 2$ represents zone 2

Fig. 4 Phenology model simulation for cv Cabernet Sauvignon (Model $\mathrm{Cab}$ ) and cv Chardonnay (Model Cha). Where: Lines represent the sum of GDD necessary to fulfill the state 23 in PS (Flowering). $\mathrm{R}^{2}$ : Represents the degree of fit between phenological stage (PS) and growing degree days (GDD)

Fig. 5 Maps of spatial distribution of the main phenological stages, field 1, 2009-10, 201011, 2011-12 and 2012-13 seasons. a) Post-Budburst, b) Flowering and c) Veraison. a), b) and c) expressed in units of phenological scale (PS)

Fig. 6 Maps of spatial distribution of the maturation, expressed in total soluble solids ( ${ }^{\circ}$ Brix), field 1, 2009-10, 2010-11, 2011-12 and 2012-13 seasons. a) Pre-Ha 1 (25 days before harvest), b) Pre-Ha 2 (12 days before harvest) and c) Ha (Harvest)

Fig. 7 Maps of spatial distribution of the main phenological stages, field 2, 2011-12 and 2012-13 seasons. a) Post-Budburst, b) Flowering and c) Veraison. a), b) and c) expressed in units of phenological scale (PS)

Fig. 8 Maps of spatial distribution of the maturation, expressed in total soluble solids ( ${ }^{\circ} \mathrm{Brix}$ ), field 2, 2011-12 and 2012-13 seasons. a) Pre-Ha 1 (25 days before harvest), b) Pre-Ha 2 (12 days before harvest) and c) $\mathrm{Ha}$ (Harvest)

Fig. 9 Air temperature (a) and growing degree-days (b) for each zone (zone 1 and 2) from the field 1 (cv Cabernet Sauvignon). Each point on the figure represents the average of 4 sensors for each zone

Fig. 10 Mapping of the cluster analysis for field 1 ( $a$ and c) and field 2 (b and d). a) and b) cluster analysis of the main phenological stages. c) and d) cluster analysis of the maturation (total soluble solids)

Fig. 11 Days difference between the defined zones (cluster analysis) according to the average of the fields, for the main phenological stages and maturation. (a) field 1 and (b) field 2 . The dashed line represents the reference level (0). Each point on the figure represents the average of all seasons considered for each cultivar (4 for field 1 and 2 for field 2). Vertical bars represent the standard deviation

\section{TABLES}

Table 1 Field characteristics of the Cabernet Sauvignon and Chardonnay experimental fields

\begin{tabular}{|c|c|c|}
\hline Property & Cabernet Sauvignon & Chardonnay \\
\hline Experimental period & $2009-13$ & 2011-13 \\
\hline Vineyard age $\mathrm{e}^{\mathrm{a}}$ & 13-year-old & 17 -year-old \\
\hline Rootstock & \multicolumn{2}{|c|}{ Own-rooted } \\
\hline Location (WGS84) & $35^{\circ} 22.0^{\prime} \mathrm{S}, 71^{\circ} 35.6^{\prime} \mathrm{W}$ & $35^{\circ} 21.9^{\prime} \mathrm{S}, 71^{\circ} 35.8^{\prime} \mathrm{W}$ \\
\hline $\begin{array}{l}\text { Elevation ( } \mathrm{m} \text { above sea } \\
\text { level) }\end{array}$ & 113.6 & 131.8 \\
\hline Spacing (m x m) & $3.0 \times 1.5$ & $3.0 \times 1.25$ \\
\hline Trellis/Pruning system & $\begin{array}{l}\text { VSPSystem/Two-bilateral spur- } \\
\text { cordon }\end{array}$ & VSPSystem/Guyot \\
\hline Row orientation & $330^{\circ} \mathrm{NW}$ & $310^{\circ} \mathrm{NW}$ \\
\hline Total root depth (m) & 0.7 & 0.8 \\
\hline
\end{tabular}


Bulk density $\left(\mathrm{g} \mathrm{cm}^{-3}\right)$ Field capacity $\left(\mathrm{m}^{3} \mathrm{~m}^{-3}\right)$ Wilting point $\left(\mathrm{m}^{3} \mathrm{~m}^{-3}\right)$ Available water $\left(\mathrm{m}^{3} \mathrm{~m}^{-3}\right)$ Texture

\section{4}

0.34

0.22

0.12

\section{5}

0.26

0.15

0.11

\section{Clay loam}

Irrigation system $\quad$ Furrow irrigation

a: at the beginning of the experiment.

VSP: Vertical shoot positional

Table 2 Representation of the phenological scale of Eichhorn and Lorenz as modified by

6 Coombe (Coombe 1995)

\begin{tabular}{|c|c|c|}
\hline $\begin{array}{l}\text { Main phenological } \\
\text { stage }\end{array}$ & $\begin{array}{l}\text { Assigned Number in } \\
\text { Scale (PS) }\end{array}$ & Meaning \\
\hline \multirow{6}{*}{$\begin{array}{l}\text { Budburst ansPost- } \\
\text { Budburst }\end{array}$} & 4 & \multirow{6}{*}{$\begin{array}{l}\text { Green tip: first leaf tissue visible (Budburst) } \\
\text { Rosette of leaf tips visible } \\
\text { First leaf separated from shoot tip } \\
2 \text { to } 3 \text { leaves separated; shoots } 2-4 \mathrm{~cm} \text { long } \\
4 \text { leaves separated } \\
5 \text { leaves separated; shoots about } 10 \mathrm{~cm} \text { long; inflorescence } \\
\text { clear }\end{array}$} \\
\hline & 5 & \\
\hline & 7 & \\
\hline & 9 & \\
\hline & 11 & \\
\hline & 12 & \\
\hline \multirow{6}{*}{ Flowering } & 19 & $\begin{array}{l}\text { About } 16 \text { leaves separated; beginning of flowering (first } \\
\text { flower caps loosening) }\end{array}$ \\
\hline & 20 & $10 \%$ caps off \\
\hline & 21 & $30 \%$ caps off \\
\hline & 23 & $17-20$ leaves separated; $50 \%$ caps off (full-bloom) \\
\hline & 25 & $80 \%$ caps off \\
\hline & 26 & Cap-fall complete $(100 \%)$ \\
\hline \multirow{4}{*}{ Veraison } & 33 & Berries still hard and green. \\
\hline & 34 & Berries begin to soften. \\
\hline & 35 & Berries begin to colour and enlarge (Veraison). \\
\hline & 36 & Berries with intermediate ${ }^{\circ}$ Brix values. \\
\hline
\end{tabular}

Table 3 Summary of thermal time and main climatic variables, which characterize the growing conditions over the 4 years of experiment. Variables are presented by phenological stage (mean of the field) with Bu: Budburst, Fl: Flowering, Ve: Veraison and Ha: Harvest. Cab: cv Cabernet Sauvignon and Cha: cv Chardonnay

\begin{tabular}{|c|c|c|c|c|c|c|c|c|c|c|}
\hline Season & \multicolumn{2}{|c|}{$\mathrm{T}_{\text {mean }}\left({ }^{\circ} \mathrm{C}\right)$} & \multicolumn{2}{|c|}{ sGDD $\left({ }^{\circ} \mathrm{C}\right)$} & \multicolumn{2}{|c|}{$\mathrm{P}(\mathrm{mm})$} & \multicolumn{2}{|c|}{$\mathrm{ET}_{0}(\mathrm{~mm})$} & \multicolumn{2}{|c|}{$\mathrm{P}-\mathrm{ET}_{0}(\mathrm{~mm})$} \\
\hline $2009-2010$ & \multicolumn{2}{|c|}{$\mathrm{Cab}$} & \multicolumn{2}{|c|}{$\mathrm{Cab}$} & \multicolumn{2}{|c|}{$\mathrm{Cab}$} & \multicolumn{2}{|c|}{$\mathrm{Cab}$} & \multicolumn{2}{|c|}{$\mathrm{Cab}$} \\
\hline 1 May-Bu & \multicolumn{2}{|c|}{8.8} & \multicolumn{2}{|c|}{123} & \multicolumn{2}{|c|}{515.8} & \multicolumn{2}{|c|}{180} & \multicolumn{2}{|c|}{336} \\
\hline $\mathrm{Bu}-\mathrm{Fl}$ & \multicolumn{2}{|c|}{14.0} & \multicolumn{2}{|c|}{264} & \multicolumn{2}{|c|}{62.0} & \multicolumn{2}{|c|}{237} & \multicolumn{2}{|c|}{-175} \\
\hline Fl-Ve & \multicolumn{2}{|c|}{19.6} & \multicolumn{2}{|c|}{625} & \multicolumn{2}{|c|}{2.8} & \multicolumn{2}{|c|}{383} & \multicolumn{2}{|c|}{-380} \\
\hline Ve-Ha ${ }^{*}$ & \multicolumn{2}{|c|}{17.4} & \multicolumn{2}{|c|}{499} & \multicolumn{2}{|c|}{0.2} & \multicolumn{2}{|c|}{245} & \multicolumn{2}{|c|}{-245} \\
\hline 1 May-Ha ${ }^{*}$ & \multicolumn{2}{|c|}{15.0} & \multicolumn{2}{|c|}{1510} & \multicolumn{2}{|c|}{580.8} & \multicolumn{2}{|c|}{1045} & \multicolumn{2}{|c|}{-464} \\
\hline $2010-2011$ & & & & & & & & & & \\
\hline 1 May-Bu & & & & & & & & & & \\
\hline $\mathrm{Bu}-\mathrm{Fl}$ & & & & & & & & & & \\
\hline Fl-Ve & & & & & & & & & & \\
\hline Ve-Ha* & & & & & & & & & & \\
\hline 1 May-Ha ${ }^{*}$ & & & & & & & & & & \\
\hline $2011-2012$ & $\mathrm{Cab}$ & Cha & $\mathrm{Cab}$ & Cha & $\mathrm{Cab}$ & Cha & $\mathrm{Cab}$ & Cha & $\mathrm{Cab}$ & Cha \\
\hline 1 May-Bu & 8.1 & 8.0 & 84 & 70 & 448.6 & 448.6 & 169 & 159 & 280 & 290 \\
\hline $\mathrm{Bu}-\mathrm{Fl}$ & 14.4 & 14.2 & 263 & 258 & 9.0 & 8.8 & 215 & 214 & -206 & -205 \\
\hline $\mathrm{Fl}-\mathrm{Ve}$ & 20.1 & 20.0 & 679 & 641 & 0.0 & 0.2 & 393 & 375 & -393 & -375 \\
\hline Ve-Ha ${ }^{*}$ & 20.2 & 20.4 & 497 & 416 & 7.0 & 7.0 & 241 & 208 & -234 & -201 \\
\hline
\end{tabular}


Author-produced version of the article published in Precision agriculture, 2015, №17(2), p. 218-245. The original publication is available at http://link.springer.com

\begin{tabular}{ccccccccccc}
\hline 1 May-Ha* & 15.7 & 15.7 & 1523 & 1385 & 464.6 & 464.6 & 1018 & 956 & -553 & -491 \\
\hline $2012-2013$ & Cab & Cha & Cab & Cha & Cab & Cha & Cab & Cha & Cab & Cha \\
1 May-Bu & 9.2 & 9.1 & 171 & 157 & 323.3 & 323.3 & 180 & 166 & 143 & 158 \\
Bu-Fl & 14.6 & 14.1 & 297 & 268 & 85.7 & 85.7 & 220 & 201 & -134 & -115 \\
Fl-Ve & 19.4 & 19.0 & 597 & 589 & 41.1 & 41.1 & 338 & 349 & -297 & -308 \\
Ve-Ha* & 19.0 & 20.0 & 575 & 509 & 10 & 10 & 268 & 237 & -258 & -227 \\
1 May-Ha $^{*}$ & 15.5 & 15.5 & 1640 & 1523 & 460.1 & 460 & 1006 & 952 & -546 & -492 \\
\hline
\end{tabular}

$\mathrm{T}_{\text {mean: }}$ average mean temperature; ${ }_{\mathrm{S}} \mathrm{GDD}$ : Sum of growing degree-days; P: Precipitation; $\mathrm{ET}_{0}$ : Evapotranspiration. *Harvest: the harvest was undertaken when the berries presented $22^{\circ}$ Brix of total soluble solids.

Table 4 Main statistics of grapevine phenology for the two fields studied

\begin{tabular}{|c|c|c|c|c|c|c|c|c|c|c|}
\hline Season & \multicolumn{2}{|c|}{ Min } & \multicolumn{2}{|c|}{ Max } & \multicolumn{2}{|c|}{ Range } & \multicolumn{2}{|c|}{ SD } & \multicolumn{2}{|c|}{ CV (\%) } \\
\hline $2009-10$ & \multicolumn{2}{|c|}{$\mathrm{Cab}$} & \multicolumn{2}{|c|}{$\mathrm{Cab}$} & \multicolumn{2}{|c|}{$\mathrm{Cab}$} & \multicolumn{2}{|c|}{$\mathrm{Cab}$} & \multicolumn{2}{|c|}{$\mathrm{Cab}$} \\
\hline Post- Bu & \multicolumn{2}{|c|}{5} & \multicolumn{2}{|c|}{7} & \multicolumn{2}{|c|}{2} & \multicolumn{2}{|c|}{0.65} & \multicolumn{2}{|c|}{10.5} \\
\hline $\mathrm{Fl}$ & \multicolumn{2}{|c|}{20} & \multicolumn{2}{|c|}{23} & \multicolumn{2}{|c|}{3} & \multicolumn{2}{|c|}{0.87} & \multicolumn{2}{|c|}{3.9} \\
\hline $\mathrm{Ve}$ & \multicolumn{2}{|c|}{34} & \multicolumn{2}{|c|}{35} & \multicolumn{2}{|c|}{1} & \multicolumn{2}{|c|}{0.34} & \multicolumn{2}{|c|}{1.0} \\
\hline $2010-11$ & \multicolumn{2}{|c|}{$\mathrm{Cab}$} & \multicolumn{2}{|c|}{$\mathrm{Cab}$} & \multicolumn{2}{|c|}{$\mathrm{Cab}$} & \multicolumn{2}{|c|}{$\mathrm{Cab}$} & \multicolumn{2}{|c|}{$\mathrm{Cab}$} \\
\hline Post- Bu & \multicolumn{2}{|c|}{5} & \multicolumn{2}{|c|}{7} & \multicolumn{2}{|c|}{2} & \multicolumn{2}{|c|}{0.47} & \multicolumn{2}{|c|}{8.3} \\
\hline $\mathrm{Fl}$ & & & & & & & & & & \\
\hline $\mathrm{Ve}$ & & & & & & & & & & \\
\hline $2011-12$ & $\mathrm{Cab}$ & Cha & $\mathrm{Cab}$ & Cha & $\mathrm{Cab}$ & Cha & $\mathrm{Cab}$ & Cha & $\mathrm{Cab}$ & Cha \\
\hline Post- Bu & 5 & 9 & 8 & 11 & 3 & 2 & 0.89 & 0.64 & 12.8 & 6.4 \\
\hline $\mathrm{Fl}$ & 21 & 22 & 25 & 25 & 4 & 3 & 1.35 & 0.69 & 5.6 & 3.0 \\
\hline $\mathrm{Ve}$ & 33 & 33 & 35 & 35 & 2 & 2 & 0.54 & 0.52 & 1.5 & 1.5 \\
\hline $2012-13$ & $\mathrm{Cab}$ & Cha & $\mathrm{Cab}$ & Cha & $\mathrm{Cab}$ & Cha & $\mathrm{Cab}$ & Cha & $\mathrm{Cab}$ & Cha \\
\hline Post- Bu & 7.0 & 7.0 & 11 & 11 & 4 & 4 & 1.05 & 1.36 & 12.1 & 15.6 \\
\hline $\mathrm{Fl}$ & 18 & 20 & 21 & 25 & 3 & 5 & 0.77 & 1.46 & 3.9 & 6.5 \\
\hline $\mathrm{Ve}$ & 34 & 33 & 35 & 35 & 1 & 2 & 0.28 & 0.97 & 0.8 & 2.9 \\
\hline
\end{tabular}
12 Bu: Post-Budbreak, Fl: Flowering, Ve: Veraison. Post-Bu, Fl and Ve expressed in PS. Cab: cv Cabernet Sauvignon, field 13 1. Cha: cv Chardonnay, field 2.

15 Table 5 Main statistics of maturation, expressed in Total Soluble Solids (TSS), for the 16 two fields studied

\begin{tabular}{|c|c|c|c|c|c|c|c|c|c|c|}
\hline Season & \multicolumn{2}{|c|}{ Min } & \multicolumn{2}{|c|}{ Max } & \multicolumn{2}{|c|}{ Range } & \multicolumn{2}{|c|}{ SD } & \multicolumn{2}{|c|}{ CV (\%) } \\
\hline $2009-10$ & \multicolumn{2}{|c|}{$\mathrm{Cab}$} & \multicolumn{2}{|c|}{$\mathrm{Cab}$} & \multicolumn{2}{|c|}{$\mathrm{Cab}$} & \multicolumn{2}{|c|}{$\mathrm{Cab}$} & \multicolumn{2}{|c|}{$\mathrm{Cab}$} \\
\hline Pre-Ha 1 & \multicolumn{2}{|c|}{17.6} & \multicolumn{2}{|c|}{21.2} & \multicolumn{2}{|c|}{3.6} & \multicolumn{2}{|c|}{0.96} & \multicolumn{2}{|c|}{4.8} \\
\hline Pre-Ha 2 & \multicolumn{2}{|c|}{18.6} & \multicolumn{2}{|c|}{22.2} & \multicolumn{2}{|c|}{3.6} & \multicolumn{2}{|c|}{1.16} & \multicolumn{2}{|c|}{5.6} \\
\hline $\mathrm{Ha}$ & \multicolumn{2}{|c|}{19.8} & \multicolumn{2}{|c|}{24.0} & \multicolumn{2}{|c|}{4.2} & \multicolumn{2}{|c|}{1.20} & \multicolumn{2}{|c|}{5.3} \\
\hline $2010-11$ & \multicolumn{2}{|c|}{$\mathrm{Cab}$} & \multicolumn{2}{|c|}{$\mathrm{Cab}$} & \multicolumn{2}{|c|}{$\mathrm{Cab}$} & \multicolumn{2}{|c|}{$\mathrm{Cab}$} & \multicolumn{2}{|c|}{$\mathrm{Cab}$} \\
\hline Pre-Ha 1 & \multicolumn{2}{|c|}{17.0} & \multicolumn{2}{|c|}{21.6} & \multicolumn{2}{|c|}{4.6} & \multicolumn{2}{|c|}{1.40} & \multicolumn{2}{|c|}{6.8} \\
\hline Pre-Ha 2 & & & & & & & & & & \\
\hline $\mathrm{Ha}$ & & & & & & & & & & \\
\hline $2011-12$ & $\mathrm{Cab}$ & Cha & $\mathrm{Cab}$ & Cha & $\mathrm{Cab}$ & Cha & $\mathrm{Cab}$ & Cha & $\mathrm{Cab}$ & Cha \\
\hline Pre-Ha 1 & 17.6 & 13.8 & 22.7 & 18.7 & 5.1 & 4.9 & 1.38 & 1.23 & 6.5 & 7.6 \\
\hline Pre-Ha 2 & 18.8 & 17.6 & 24.6 & 22.0 & 5.8 & 4.4 & 1.31 & 1.04 & 5.9 & 5.3 \\
\hline $\mathrm{Ha}$ & 18.8 & 18.5 & 24.6 & 22.9 & 5.8 & 4.4 & 1.31 & 1.02 & 5.9 & 4.9 \\
\hline $2012-13$ & $\mathrm{Cab}$ & Cha & $\mathrm{Cab}$ & Cha & $\mathrm{Cab}$ & Cha & $\mathrm{Cab}$ & Cha & $\mathrm{Cab}$ & Cha \\
\hline Pre-Ha 1 & 15.6 & 15.0 & 20.9 & 19.0 & 5.3 & 4.0 & 1.38 & 1.16 & 7.1 & 6.7 \\
\hline Pre-Ha 2 & 17.2 & 18.8 & 22.4 & 21.5 & 5.2 & 2.7 & 1.37 & 0.76 & 6.5 & 3.8 \\
\hline $\mathrm{Ha}$ & 18.3 & 21.0 & 23.9 & 23.9 & 5.6 & 2.9 & 1.50 & 0.77 & 6.8 & 3.4 \\
\hline
\end{tabular}

17 Min:minumun, Max: Maximun, SD: Standard deviation, CV: Coefficiente of variation, Range: Range of variation. Pre-Ha 18 1: 20 days before Harvest, Pre-Ha 2: 12 days before Harvest. Ha: Harvest. Pre-Ha 1, Pre-Ha 2 and Ha expressed in ${ }^{\circ}$ Brix. 19 Cab: cv Cabernet Sauvignon, field 1. Cha: cv Chardonnay, field 2. 
Author-produced version of the article published in Precision agriculture, 2015, №17(2), p. 218-245. The original publication is available at http://link.springer.com

Table 6 Parameters of semivariogram adjusted for each phenological stage evaluated

4 in the seasons

\begin{tabular}{cccccccc}
\hline \multicolumn{7}{c}{ Components of Semivariogram } \\
\hline Season & Model & $\mathrm{R}^{2}$ & $\mathrm{C}_{0}$ & $\mathrm{C}_{0}+\mathrm{C}$ & $\mathrm{a}$ & DESP (\%) & MCD (m) \\
\hline $2009-10 \mathrm{Cab}$ & & & & & & & \\
Post- Bu & $\mathrm{G}$ & 0.98 & 0.001 & 0.472 & 80.7 & 0.21 & 30.2 \\
Fl & $\mathrm{Sp}$ & 0.99 & 0.017 & 0.901 & 100.1 & 1.89 & 36.8 \\
Ve & $\mathrm{G}$ & 0.86 & 0.0002 & 0.162 & 92.3 & 0.12 & 34.6 \\
$2010-11 \mathrm{Cab}$ & & & & & & & \\
Post- Bu & $\mathrm{G}$ & 0.99 & 0.0018 & 0.266 & 72.6 & 0.68 & 27.0 \\
Fl & $\mathrm{G}$ & 0.77 & 0.001 & 2.85 & 81.8 & 0.04 & 30.7 \\
Ve & $\mathrm{G}$ & 0.99 & 0.0032 & 0.1053 & 112.4 & 3.04 & 40.9 \\
$2011-12 \mathrm{Cab}$ & & & & & & & \\
Post- Bu & $\mathrm{G}$ & 0.99 & 0.006 & 0.859 & 65.82 & 0.70 & 24.5 \\
Fl & $\mathrm{G}$ & 0.99 & 0.058 & 2.644 & 98.2 & 2.19 & 36.0 \\
Ve & $\mathrm{G}$ & 0.83 & 0.0001 & 0.298 & 95.44 & 0.03 & 35.8 \\
$2012-13 \mathrm{Cab}$ & & & & & & & \\
Post- Bu & $\mathrm{G}$ & 0.74 & 0.060 & 1.148 & 47.1 & 5.23 & 16.7 \\
Fl & $\mathrm{G}$ & 0.97 & 0.0010 & 0.686 & 67.4 & 0.15 & 25.2 \\
Ve & $\mathrm{G}$ & 0.97 & 0.0001 & 0.128 & 123.3 & 0.08 & 46.2 \\
$2011-12 \mathrm{Cha}$ & & & & & & & \\
Post- Bu & $\mathrm{G}$ & 0.93 & 0.034 & 0.676 & 115.4 & 5.03 & 41.1 \\
Fl & $\mathrm{G}$ & 0.95 & 0.0010 & 0.551 & 54.7 & 0.18 & 20.5 \\
Ve & $\mathrm{Sp}$ & 0.83 & 0.0010 & 1.520 & 97.3 & 0.07 & 36.5 \\
$2012-13 \mathrm{Cha}$ & & & & & & & \\
Post- Bu & $\mathrm{G}$ & 0.99 & 0.166 & 2.964 & 106.9 & 5.60 & 37.8 \\
Fl & $\mathrm{G}$ & 0.99 & 0.513 & 2.911 & 97.9 & 17.62 & 30.2 \\
Ve & $\mathrm{G}$ & 0.99 & 1.165 & 9.486 & 149.1 & 12.28 & 49.0 \\
\hline
\end{tabular}

$5 \quad \mathrm{C}_{0}$ : Nugget. $\mathrm{C}_{0}+\mathrm{C}$ : Sill. a: Range. DESP (\%) Degree of spatial dependence. G: Gaussian, Ex: Exponential, Sp: Spherical, 6 L: Linear. Post-Bu: Post-Budbreak, Fl: Flowering, Ve: Veraison. Post-Bu, Fl and Ve expressed in PS. Cab: cv Cabernet 7 Sauvignon, field 1. Cha: cv Chardonnay, field 2.

10 Table 7 Parameters of semivariogram adjusted for each maturation date evaluated in 11 the seasons

\begin{tabular}{|c|c|c|c|c|c|c|c|}
\hline \multicolumn{8}{|c|}{ Components of Semivariogram } \\
\hline Season & Model & $\mathrm{R}^{2}$ & $\mathrm{C}_{0}$ & $\mathrm{C}_{0}+\mathrm{C}$ & $\mathrm{a}$ & DESP $(\%)$ & $\operatorname{MCD}(\mathrm{m})$ \\
\hline \multicolumn{8}{|l|}{ 2009-10 Cab } \\
\hline Pre-Ha 1 & G & 0.94 & 0 & 1.041 & 32.9 & 0.00 & 12.3 \\
\hline Pre-Ha 2 & G & 0.93 & 0 & 1.420 & 41.0 & 0.00 & 15.4 \\
\hline На & G & 0.91 & 0.001 & 1.470 & 68.4 & 0.07 & 25.6 \\
\hline \multicolumn{8}{|l|}{ 2010-11 Cab } \\
\hline Pre-Ha 1 & G & 0.98 & 0 & 2.031 & 31.6 & 0.00 & 11.8 \\
\hline Pre-Ha 2 & G & 0.96 & 0 & 2.625 & 30.3 & 0.00 & 11.4 \\
\hline $\mathrm{Ha}$ & G & 0.76 & 0.0010 & 2.702 & 64.95 & 0.04 & 24.3 \\
\hline \multicolumn{8}{|l|}{ 2011-12 Cab } \\
\hline Pre-Ha 1 & G & 0.90 & 0.0000 & 1.846 & 31.6 & 0.00 & 11.8 \\
\hline Pre-Ha 2 & G & 0.92 & 0.0000 & 1.793 & 35.9 & 0.00 & 13.5 \\
\hline $\mathrm{Ha}$ & G & 0.88 & 0.0010 & 1.687 & 58.72 & 0.06 & 22.0 \\
\hline \multicolumn{8}{|l|}{ 2012-13 Cab } \\
\hline Pre-Ha 1 & G & 0.91 & 0.2023 & 1.618 & 37.49 & 12.5 & 12.3 \\
\hline Pre-Ha 2 & G & 0.93 & 0.0000 & 2.161 & 39.98 & 0.00 & 15.0 \\
\hline $\mathrm{Ha}$ & G & 0.99 & 0.0010 & 2.627 & 92.49 & 0.04 & 34.7 \\
\hline \multicolumn{8}{|l|}{ 2011-12 Cha } \\
\hline Pre-Ha 1 & G & 0.92 & 0.1319 & 1.693 & 38.2 & 7.79 & 13.2 \\
\hline Pre-Ha 2 & G & 0.93 & 0.0000 & 1.148 & 22.8 & 0.00 & 8.6 \\
\hline $\begin{array}{c}\mathrm{Ha} \\
2012-13 \mathrm{Cha}\end{array}$ & $\mathrm{L}$ & 0.95 & 0.1415 & - & - & - & - \\
\hline
\end{tabular}




$\begin{array}{cccccccc}\text { Pre-Ha 1 } & \text { G } & 0.89 & 0.4011 & 2.228 & 114.9 & 18.00 & 35.3 \\ \text { Pre-Ha 2 } & \text { G } & 0.91 & 0.127 & 0.955 & 82.4 & 13.33 & 26.8 \\ \text { Ha } & \text { G } & 0.67 & 0.395 & 2.800 & 119.3 & 14.11 & 38.4\end{array}$

1 Co: Nugget. $\mathrm{C}_{0}+\mathrm{C}$ : Sill. a: Range. DESP (\%) Degree of spatial dependence. G: Gaussian, Ex: Exponential, Sp: Spherical,
L: Linear. Pre-Ha 1:25 days before Harvest, Pre-Ha 2: 12 days before Harvest. Ha: Harvest. Pre-Ha 1, Pre-Ha 2 and Ha expressed in ${ }^{\circ}$ Brix. Cab: cv Cabernet Sauvignon, field 1. Cha: cv Chardonnay, field 2.

Table 8 Kendall Coefficient of Concordance (W) for phenological stage and maturation

6 throughout all the seasons (4 for field 1 and 2 for field 2)

\begin{tabular}{lll}
\hline $\begin{array}{l}\text { Phenological Stage and } \\
\text { maturation }\end{array}$ & W Kendall & Significance $(\mathrm{p}<0.01)$ \\
\hline Cabernet Sauvignon (Field 1) & & $* *$ \\
Post-Budburst & 0.51 & $* *$ \\
Flowering & 0.67 & $* *$ \\
Veraison & 0.67 & $* *$ \\
Pre-Ha 1 & 0.69 & $* *$ \\
Pre-Ha 2 & 0.65 & $* *$ \\
Harvest & 0.70 & \\
\hline Chardonnay (Field 2) & & \\
Post-Budburst & 0.85 & $* *$ \\
Flowering & 0.77 & $* *$ \\
Veraison & 0.51 & $* *$ \\
Pre-Ha 1 & 0.77 & $* *$ \\
Pre-Ha 2 & 0.51 & $* *$ \\
Harvest & 0.65 & $* *$ \\
\hline
\end{tabular}

\section{0 within the seasons}

\begin{tabular}{lll}
\hline Season & W Kendall & Significance $(\mathrm{p}<0.01)$ \\
\hline Cabernet Sauvignon (Field 1) & & \\
$2009-2010$ & & $* *$ \\
PS & 0.72 & $* *$ \\
Ma & 0.83 & \\
$2010-2011$ & & $* *$ \\
PS & 0.76 & $* *$ \\
Ma & 0.87 & \\
$2011-2012$ & & $* *$ \\
PS & 0.85 & $* *$ \\
Ma & 0.80 & \\
2012-2013 & & $* *$ \\
PS & 0.72 & $* *$ \\
Ma & 0.88 & \\
\hline Chardonnay (Field 2) & & \\
2011-2012 & & \\
PS & 0.54 & $* *$ \\
Ma & 0.80 & $* *$ \\
2012-2013 & & \\
PS & 0.81 & $* *$ \\
Ma & 0.78 & $* *$ \\
\hline
\end{tabular}

11

Ps: Phenological stage, Ma: Maturation 


\section{FIGURES}

Figure 1



Figure 2
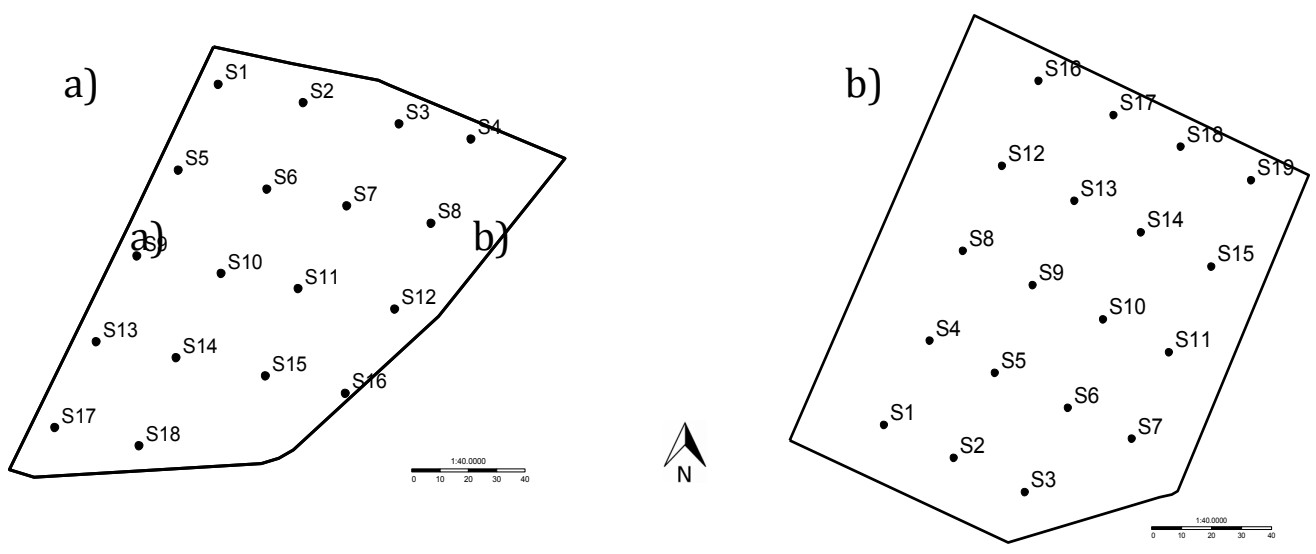


\section{Figure 3}

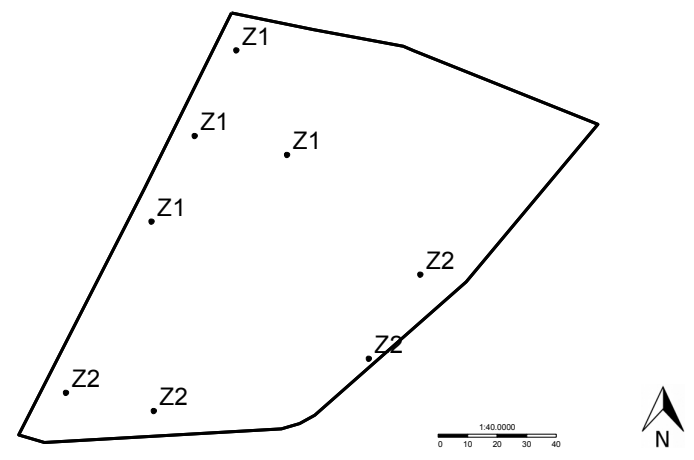

Figure 4

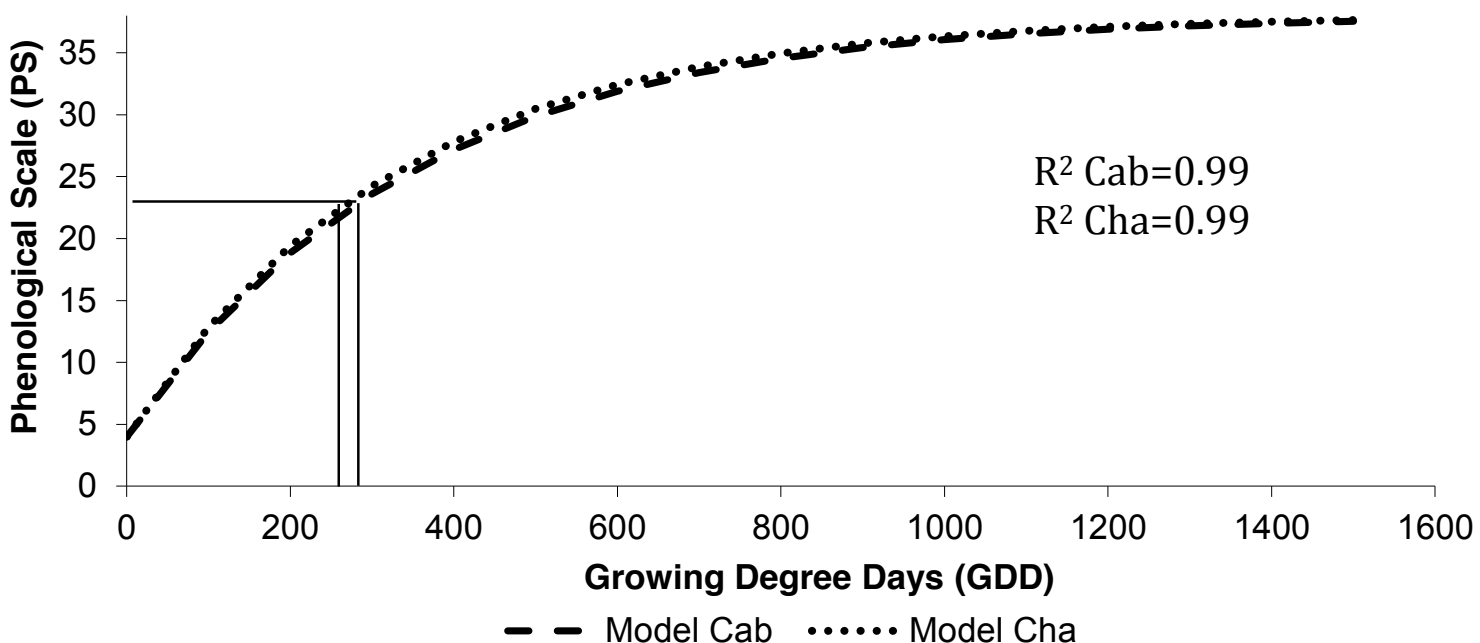


Author-produced version of the article published in Precision agriculture, 2015, №17(2), p. 218-245. The original publication is available at http://link.springer.com Doi: 10.1007/s11119-015-9418-5

Figure 5

$2009-10$

a)
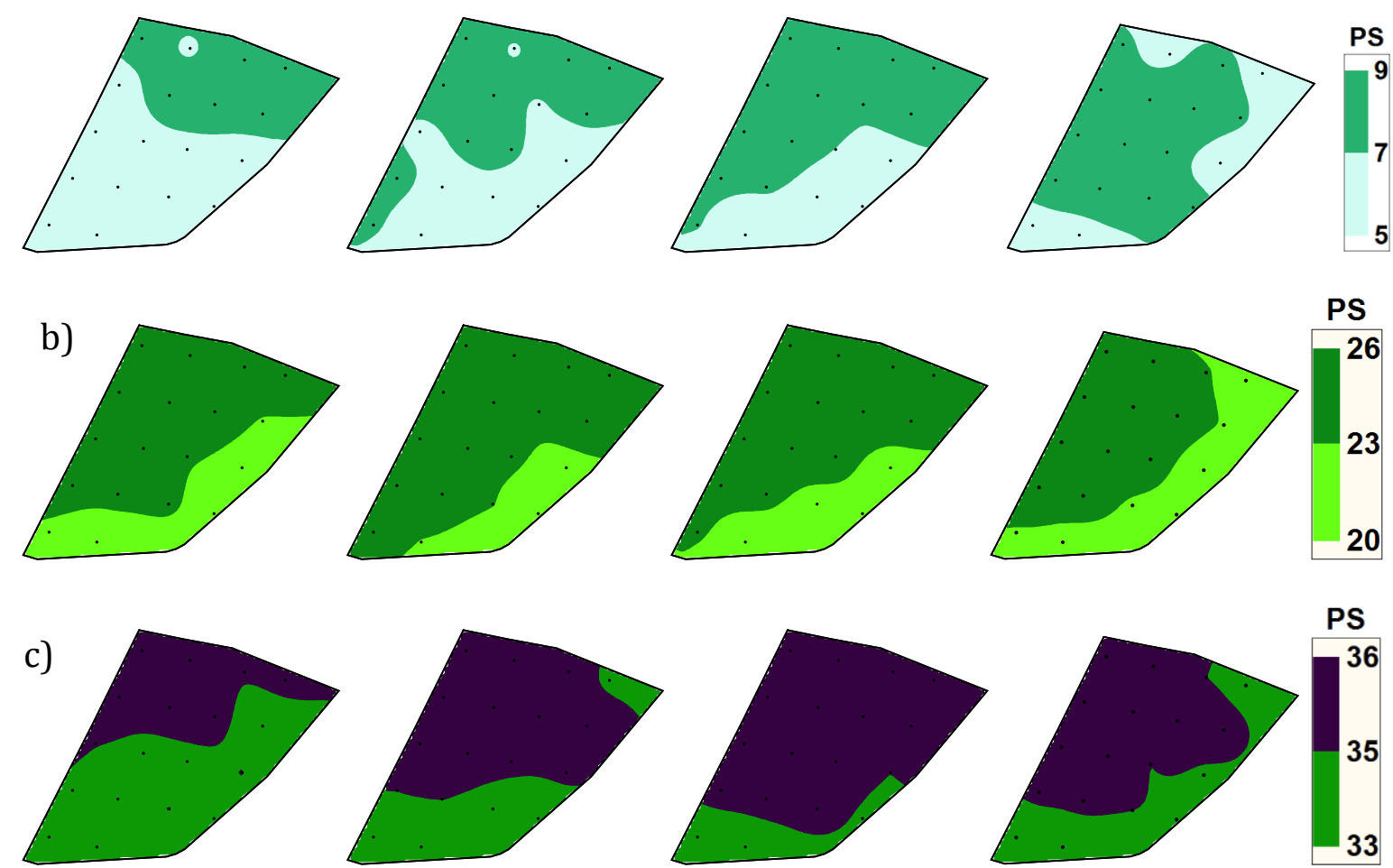

$2011-$

12
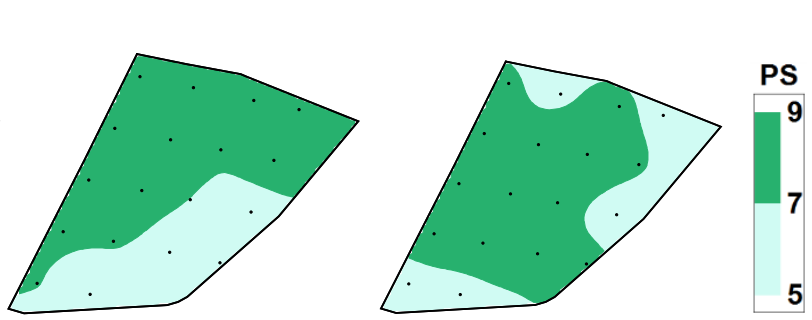

2012-

13
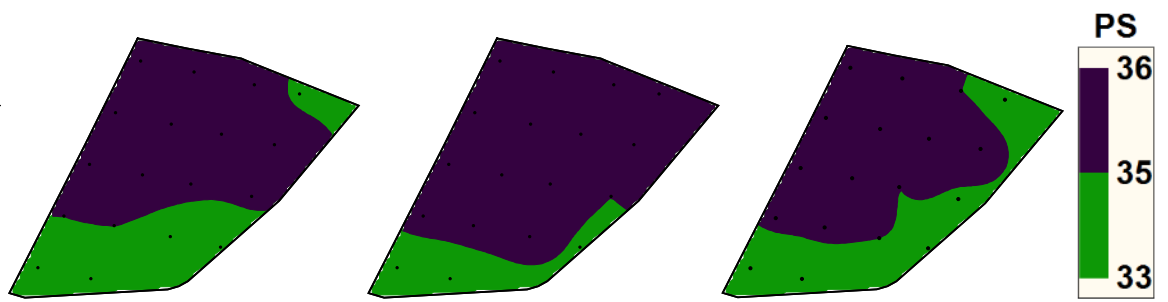

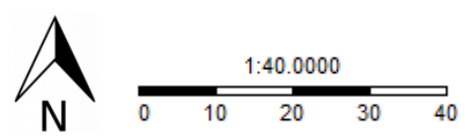


Author-produced version of the article published in Precision agriculture, 2015, №17(2), p. 218-245. The original publication is available at http://link.springer.com Doi: 10.1007/s11119-015-9418-5

Figure 6




Author-produced version of the article published in Precision agriculture, 2015, N¹7(2), p. 218-245.

The original publication is available at http://link.springer.com

Doi: 10.1007/s11119-015-9418-5

Figure 7
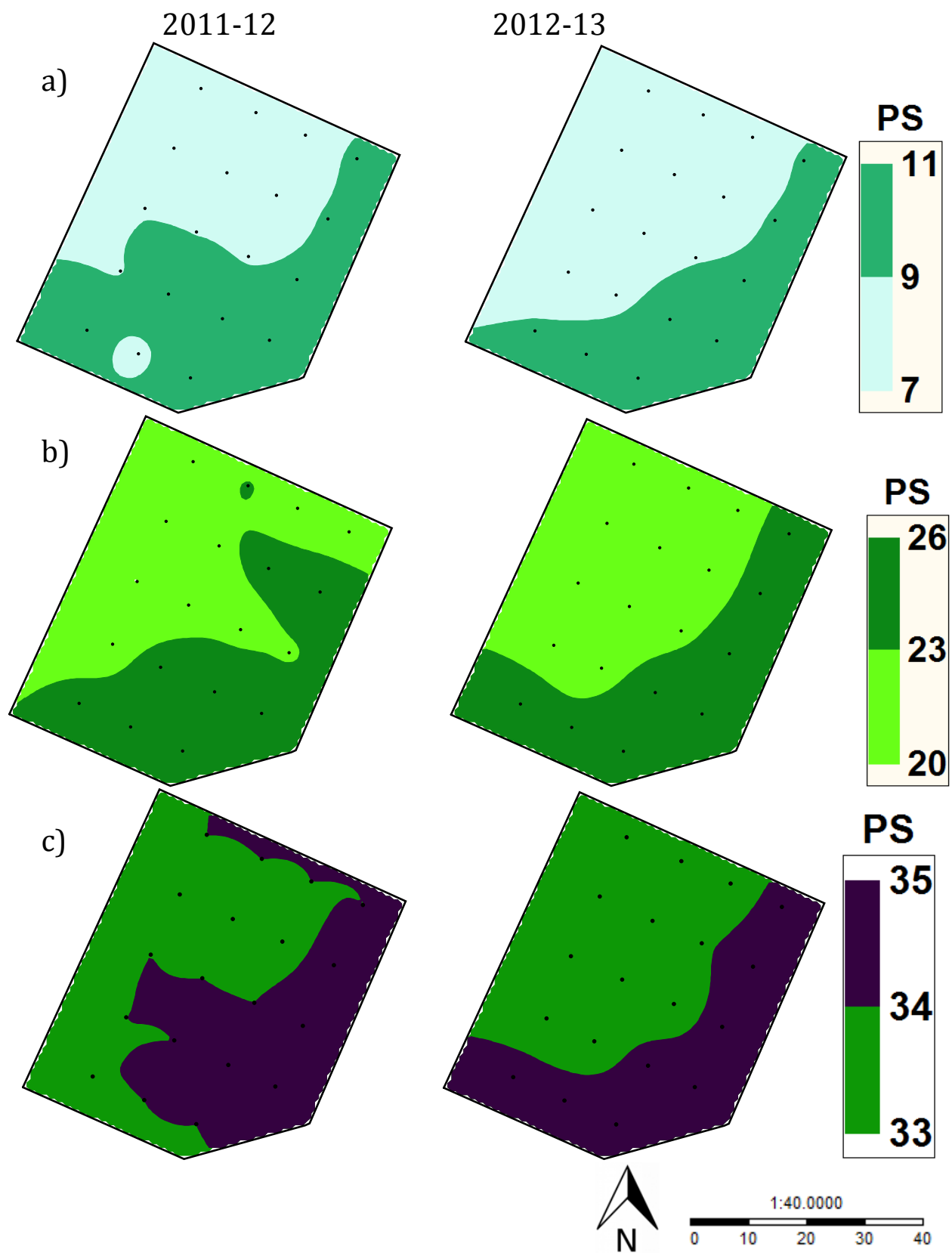
Author-produced version of the article published in Precision agriculture, 2015, N¹7(2), p. 218-245.

The original publication is available at http://link.springer.com

Doi: 10.1007/s11119-015-9418-5

Figure 8

2011-12

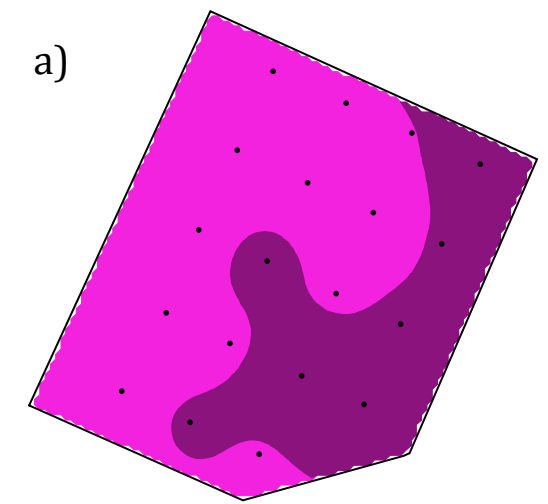

b)
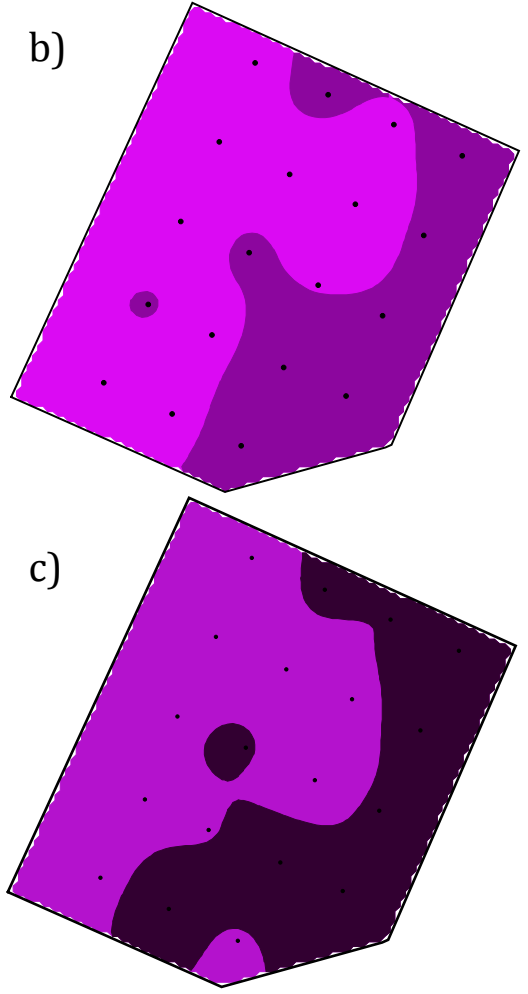

$2012-13$

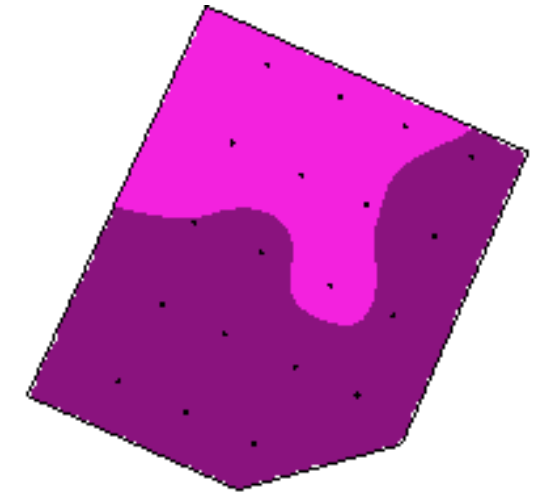

15.0

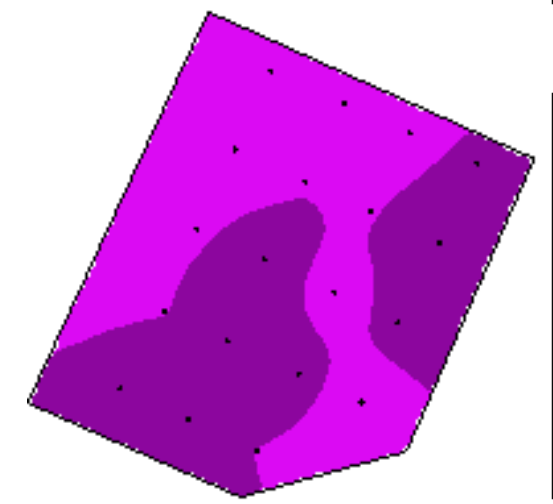

${ }^{\circ}$ Brix
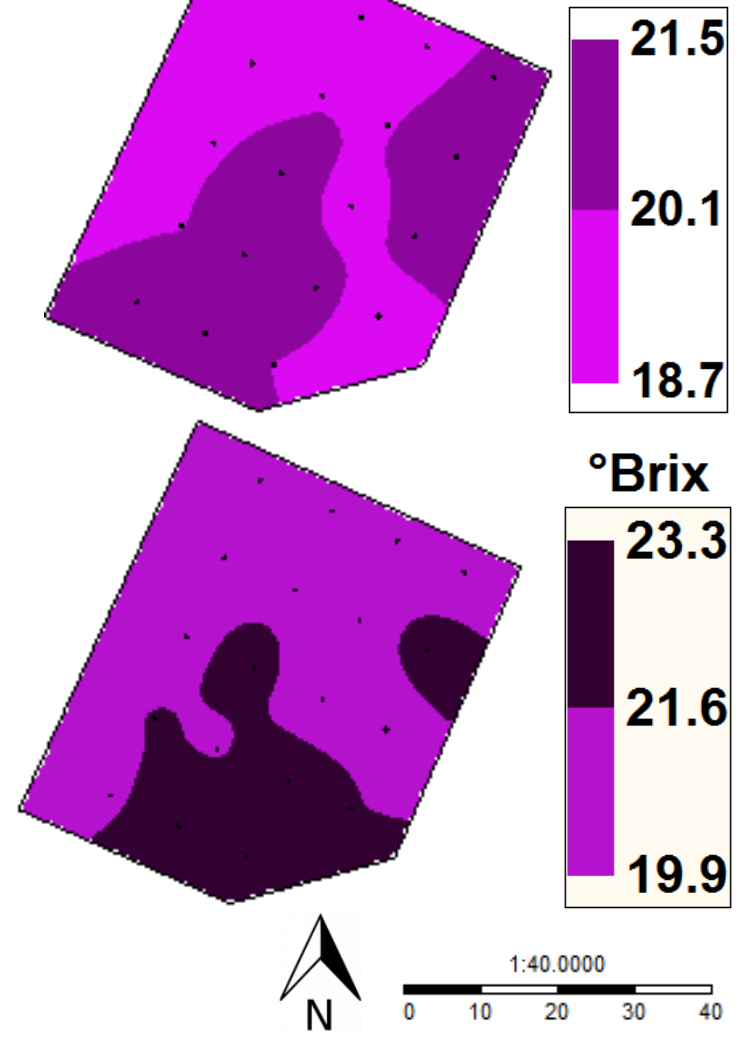
Author-produced version of the article published in Precision agriculture, 2015, N¹7(2), p. 218-245.

The original publication is available at http://link.springer.com

Doi: 10.1007/s11119-015-9418-5

Figure 9

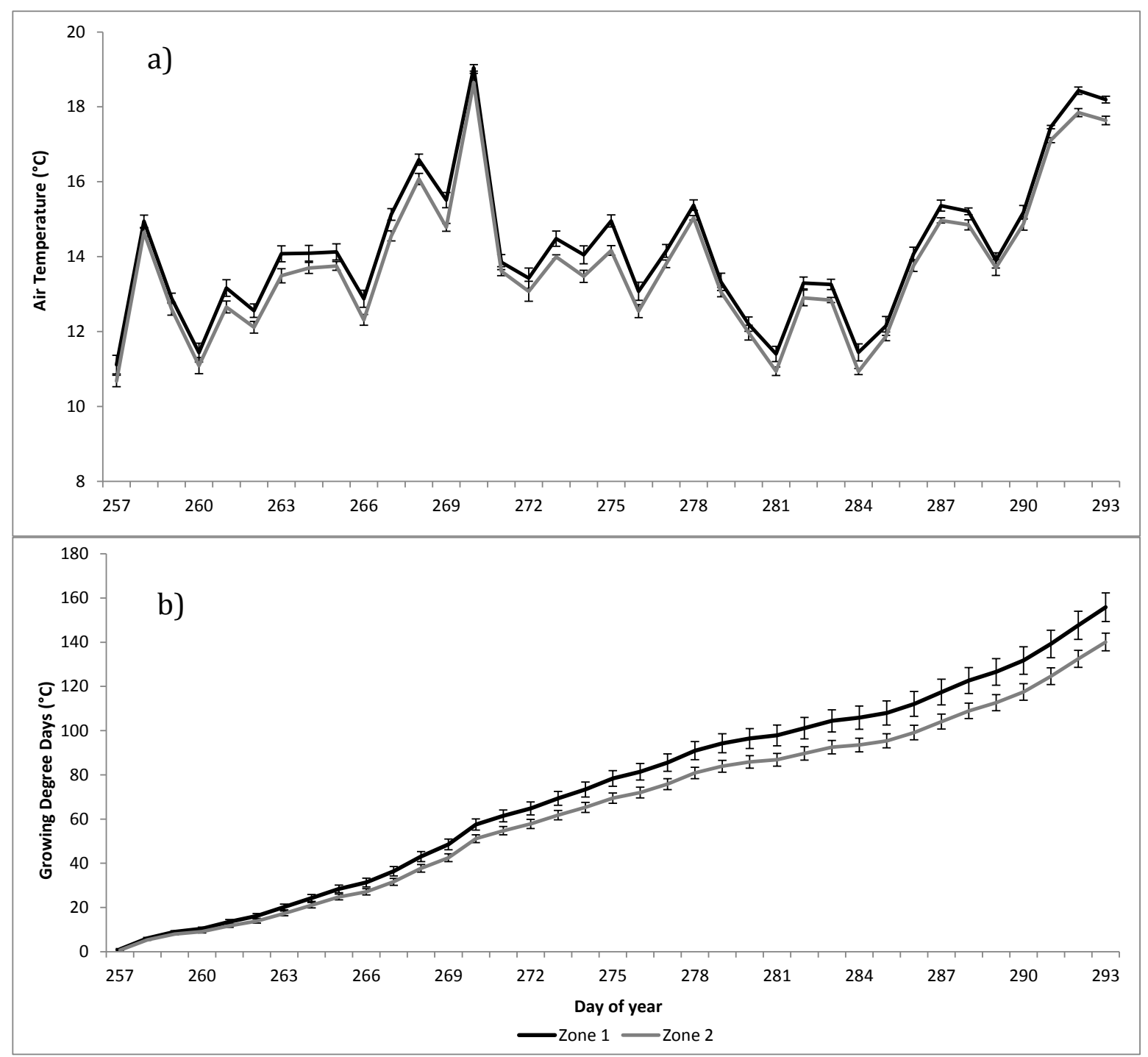


Author-produced version of the article published in Precision agriculture, 2015, N¹7(2), p. 218-245. The original publication is available at http://link.springer.com Doi: 10.1007/s11119-015-9418-5

Figure 10




Figure 11

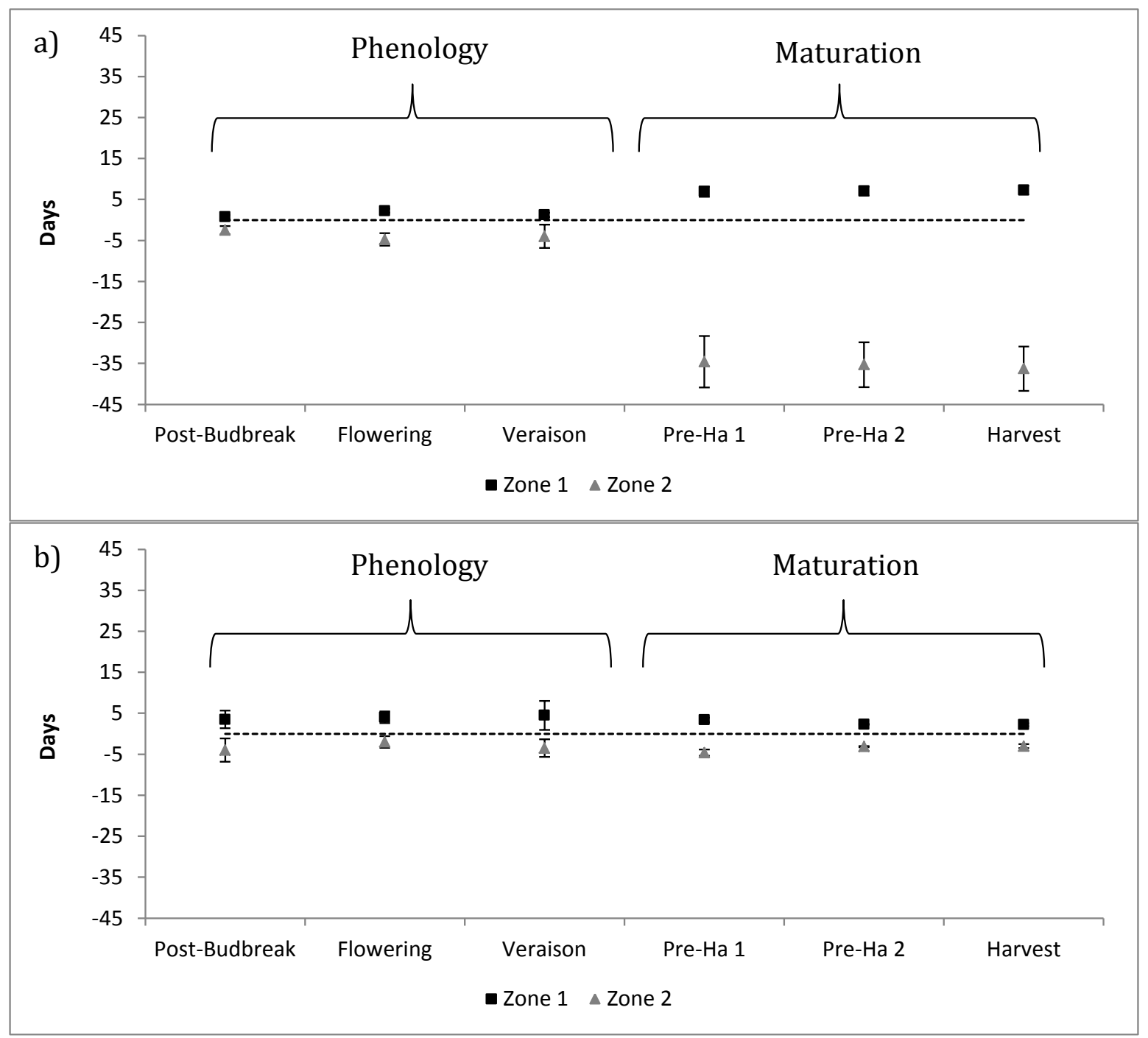

